Furan-PNA: a mildly inducible irreversible interstrand crosslinking system targeting single and double stranded DNA - Electronic Supporting Information

\title{
Furan-PNA: a mildly inducible irreversible interstrand crosslinking system targeting single and double stranded DNA
}

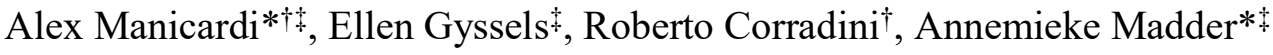 \\ ${ }^{\dagger}$ Department of Chemistry, University of Parma, Parco Area delle Scienze 17/A, Parma 43124, Italy \\ $¥$ Organic and Biomimetic Chemistry Research Group, Department of Organic Chemistry, Ghent University, Krijgslaan \\ 281-S4, Gent 9000, Belgium.
}

\section{Electronic Supporting Information - Table of contents}

General 2

Probe synthesis

Scheme S1: synthesis of the PNA monomers used in this study

Monomer synthesis

PNA synthesis

Comparison of cleavage cocktails for the protection of furan

General protocol for click reaction

UPLC-MS characterization

Fig. S1: MALDI spectrum and HPLC1-UV profiles of different cleavage cocktails

Measurements of $\mathbf{T}_{\mathrm{m}}$ values

Table S1: melting temperature of the PNA:DNA complexes

General protocol for crosslink reaction

General protocol for PAGE

PAGE experiments

Fig. S2: full denaturing PAGE picture of the PNA:DNA crosslink experiment

Fig. S3: full denaturing PAGE picture of the PNA:DNA crosslink experiment with long sequences

Fig. S4: denaturing PAGE experiments for PNA T(f) probe

Fig. S5: full denaturing PAGE picture of the strand invasion crosslink experiments

Fig. S6: effect of $2 \%$ DMF in strand displacement crosslink experiments

Table S2: densitometric evaluation of the ICL regions of PAGE shown in Fig 3 and Fig. S2

Fig. S7: histogram representation of the data presented in Table S2

Table S3: densitometric evaluation of the ICL regions of PAGE shown in Fig 5 and Fig. S5

Fig. S8: histogram representation of the data presented in Table S3

Identification of the ICL products

Fig. S9: example of HPLC trace of the ICL experiments

Fig. S10: HPLC trace of purified regions of a PNA F+ DNA A sample

Fig. S11: MALDI spectra of the isolated peaks

Table S4: weighted average of the ICL MALDI peaks

NMR spectra

Fig. S12: ${ }^{1} \mathrm{H}-\mathrm{NMR}$ and ${ }^{13} \mathrm{C}-\mathrm{NMR}$ (APT) of compound $\mathbf{1}$

Fig. S13: ${ }^{1} \mathrm{H}-\mathrm{NMR}$ and ${ }^{13} \mathrm{C}-\mathrm{NMR}$ (APT) of compound 2

Fig. S14: ${ }^{1} \mathrm{H}-\mathrm{NMR}$ and ${ }^{13} \mathrm{C}-\mathrm{NMR}$ (APT) of compound 3

Fig. S15: ${ }^{1} \mathrm{H}-\mathrm{NMR}$ and ${ }^{13} \mathrm{C}-\mathrm{NMR}$ (APT) of compound 4

Fig. S16: ${ }^{1} \mathrm{H}-\mathrm{NMR}$ and ${ }^{13} \mathrm{C}-\mathrm{NMR}$ (APT) of compound 5

Fig. S17: ${ }^{1} \mathrm{H}-\mathrm{NMR}$ and ${ }^{13} \mathrm{C}-\mathrm{NMR}$ (APT) of compound 6 
Furan-PNA: a mildly inducible irreversible interstrand crosslinking system targeting single and double stranded DNA - Electronic Supporting Information

\section{General}

All solvents and chemical reagents were purchased from Sigma-Aldrich in the highest purity available. Nonmodified DNA sequences were purchased from Eurogentec (Seraing, Belgium).

${ }^{1} \mathrm{H}$ NMR and ${ }^{13} \mathrm{C}$ NMR spectra were recorded on a Bruker Avance 300 or a Brucker DRX 500 spectrometer operating at room temperature. Chemical shifts are reported in parts per million relative to the residual solvent peak. Multiplicities are reported as singlet (s), doublet (d), doublet of doublets (dd), triplet (t) or multiplet (m).

$\underline{\text { LC-MS }}$ data were collected on an Agilent 1100 Series instrument with a Phenomenex Kinetex C18 $100 \AA$ column $\left(150 \times 4.6 \mathrm{~mm}, 5 \mu \mathrm{m}\right.$ at $\left.35{ }^{\circ} \mathrm{C}\right)$ connected to an ESMSD type VL mass detector (quadrupole ion trap mass spectrometer) with a flow rate of $1.5 \mathrm{ml} / \mathrm{min}$ was used with the following solvent systems: (A): $0.1 \% \mathrm{HCOOH}$ in $\mathrm{H}_{2} \mathrm{O}$ and (B) MeCN. The column was flushed with $100 \%$ A for $2 \mathrm{~min}$, then a gradient from 0 to $100 \% \mathrm{~B}$ over 6 min was used, followed by 2 min of flushing with $100 \%$ B. UPLC-ESI-Q data were collected on a Waters Acquity UPLC system equipped with a Waters Acquity UPLC BEH C18 column $(12.1 \times 50 \mathrm{~mm}, 1.7 \mu \mathrm{m})$ at $35^{\circ} \mathrm{C}$. A flow rate of $0.25 \mathrm{ml} / \mathrm{min}$ was used with the following solvent systems: (A): $0.2 \% \mathrm{FA}$ in $\mathrm{H}_{2} \mathrm{O}$ and (B): $0.2 \% \mathrm{FA}$ in $\mathrm{MeCN}$. The column was flushed for 0.9 min with solvent $\mathrm{A}$, then a gradient from 0 to $50 \% \mathrm{~B}$ in $5.7 \mathrm{~min}$. $\underline{\mathrm{RP}-}$ $\underline{\text { HPLC }}$ analyses were recorded on an Agilent 1100 Series instrument with a Phenomenex Luna C18 column (250 $\mathrm{x} 4.6 \mathrm{~mm}, 5 \mu \mathrm{m}$ ) at $35^{\circ} \mathrm{C}$. A flow rate of $1 \mathrm{ml} / \mathrm{min}$ was used with the following solvent systems: (A): $0.1 \%$ TFA in $\mathrm{H}_{2} \mathrm{O}$ and (B): $\mathrm{MeCN}$. The column was flushed for 5 min with solvent $\mathrm{A}$, then a gradient from 0 to $50 \% \mathrm{~B}$ in 30 min and to $100 \%$ B (HPLC1) or recorded on an Agilent 1200 system equipped with an Aeris Widepore column $(150 \times 4,6 \mathrm{~mm}, 3.6 \mu \mathrm{m})$ at $60^{\circ} \mathrm{C}$. A flow rate of $0.8 \mathrm{~mL} / \mathrm{min}$ was used with following solvent systems: (A): $0.1 \mathrm{M}$ TEAA-buffer (with 5\% MeCN) and (B): MeCN. The column was flushed for 2 min with solvent A, then a gradient from 0 to $12 \%$ B in 13 min and to $99 \%$ B in 1 min was used, followed by a flush of 5 min with 99\% B (HPLC2). MALDI-TOF spectra were acquired on an ABI Voyager DE-STR MALDI-TOF with a high performance nitrogen laser $(337 \mathrm{~nm})$, using the positive and reflector mode with delayed extraction. The matrix solution utilized was prepared as follows: $10 \mathrm{mg}$ 2,5-Dihydroxybenzoic acid in $100 \mu \mathrm{L} \mathrm{mQ/MeCN} \mathrm{2:1} \mathrm{with} 1 \%$ TFA. Concentrations of DNA- and PNA-solutions were measured with a Trinean DropSense96 UV/VIS droplet reader. Thermal denaturation experiments were recorded on a Varian Cary 300 Bio instrument equipped with a six-cell thermostatted cell holder. Densitometric evaluation was performed using the program ImageJ 1.50.b, indication of the mean density is provided, together with the minimum and maximum value of intensity (0-255 range). 


\section{Probe synthesis}

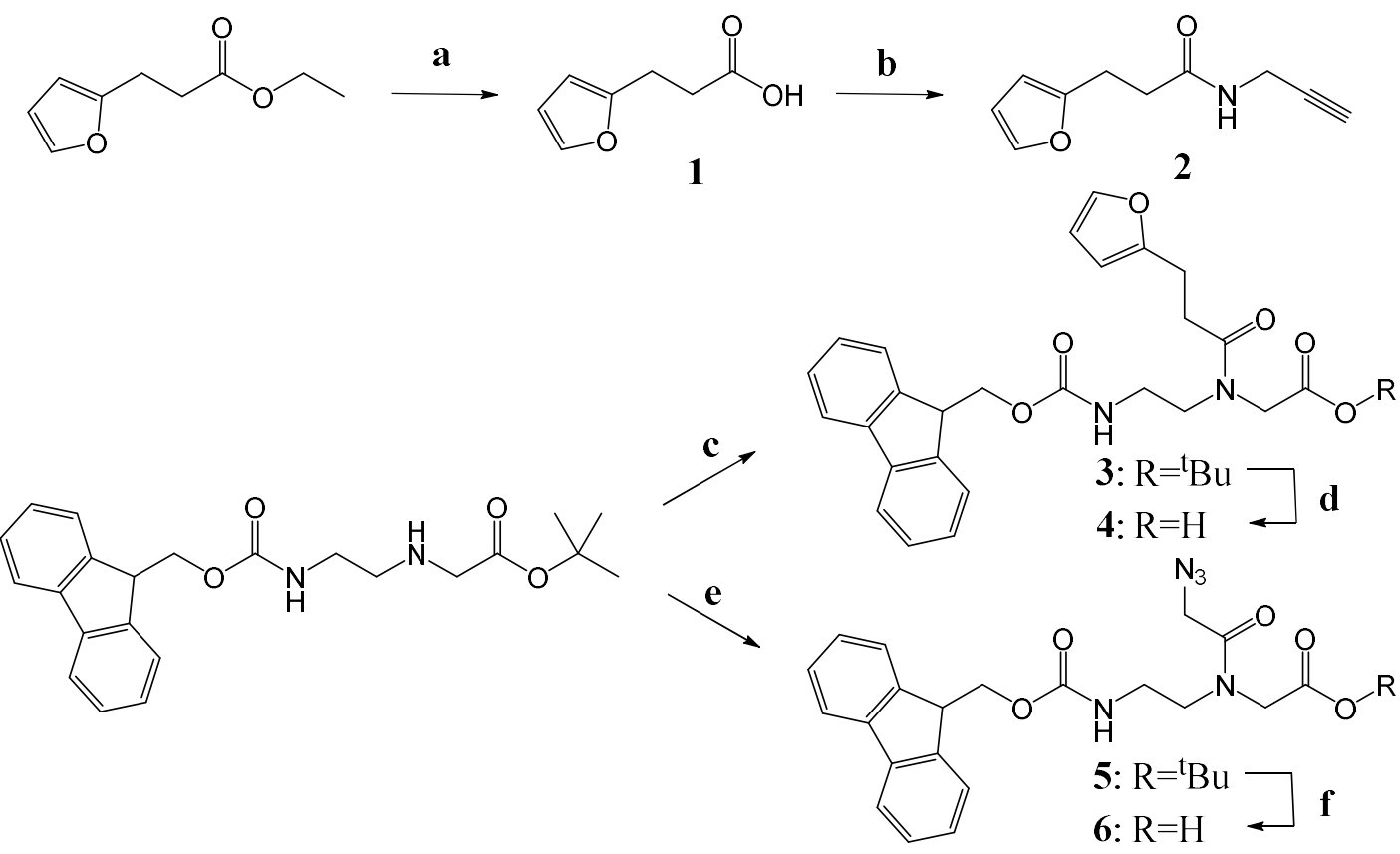

Scheme S1: synthesis of the PNA monomers used in this study.

3-(furan-2-yl)-propanoic acid (1): in a round bottom flask ethyl 3-(furan-2-yl)-propanoate (990.3mg, 5.89mmol, 1eq) was dissolved in $20 \mathrm{~mL}$ THF. The solution was then cooled to $0^{\circ} \mathrm{C}$ with an ice bath before the addition of $\mathrm{LiOH}(988.5 \mathrm{mg}, 23.56 \mathrm{mmol}, 4 \mathrm{eq})$ dissolved in $20 \mathrm{~mL}$ water. After 5 minutes the solution was allowed to warm to r.t. and to react for $2 \mathrm{~h}$ before removing the organic solvent under reduced pressure. The $\mathrm{pH}$ of the solution was lowered to 3 with concentrated $\mathrm{HCl}$ and the precipitation was favored for $2 \mathrm{~h}$ at $4{ }^{\circ} \mathrm{C}$. The precipitate was then collected through Buchner filtration, and a second aliquot of product was obtained by extraction of the solution with AcOEt $(2 \times 20 \mathrm{~mL})$. Combining the two fractions 1 was obtained as a white solid in $85.6 \%$ yield $(706.5 \mathrm{mg})$. TLC (AcOEt) Rf: 0.40; ${ }^{1} \mathbf{H}$ NMR (DMSO-d $\left.{ }^{\mathbf{6}}, \mathbf{4 0 0 M H z}\right) \boldsymbol{\delta}(\mathbf{p p m}): 12.20(\mathrm{~s}, 1 \mathrm{H}), 7.50(\mathrm{dd}, J=1.8,0.8 \mathrm{~Hz}, 1 \mathrm{H}$ ), 6.34 (dd, $J=3.1,1.9 \mathrm{~Hz}, 1 \mathrm{H}), 6.09$ (ddd, $J=2.9,1.8,0.9 \mathrm{~Hz}, 1 \mathrm{H}), 2.83$ (t, $J=7.4 \mathrm{~Hz}, 2 \mathrm{H}), 2.54$ (t, $J=7.4 \mathrm{~Hz}$, $2 \mathrm{H}) ;{ }^{13} \mathbf{C}$ NMR (DMSO-d $\left.{ }^{6}, \mathbf{1 0 0 M H z}\right) \boldsymbol{\delta}(\mathbf{p p m}): 173.8,154.8,141.8,110.8,105.6,32.4,23.4$; HR-MS (ESI, MeOH): $m / z$ calcd for $\left[\mathrm{C}_{7} \mathrm{H}_{7} \mathrm{O}_{3}\right]:$ : 139.04007 , found: 139.04041 .

3-(furan-2-yl)-N-(prop-2-yn-1-yl)propanamide (2): in a round bottom flask 1 (56.1 $\mathrm{mg}, 0.400 \mathrm{mmol}$, 1eq) and HBTU $(159.4 \mathrm{mg}, 0.420,1.05 \mathrm{eq})$ were dissolved in $2 \mathrm{~mL}$ DMF. The solution was then cooled to $0^{\circ} \mathrm{C}$ with an ice bath before the addition of DIPEA $(135.63 \mu \mathrm{L}, 0.821 \mathrm{mmol}, 2.05 \mathrm{eq})$. The reaction was left to stir at $0^{\circ} \mathrm{C}$ for 15 minutes followed by 15 minutes at r.t.. Finally, propargylamine $(51.28 \mu \mathrm{L}, 0.801 \mathrm{mmol}$, 2eq) was added to the mixture and left to react for $5 \mathrm{~h}$. The reaction was then diluted with AcOEt $(50 \mathrm{~mL})$ and washed with $0.1 \mathrm{M} \mathrm{HCl}$ $(2 \times 50 \mathrm{~mL})$, saturated aq. $\mathrm{NaHCO}_{3}(2 \times 50 \mathrm{~mL})$ and brine $(50 \mathrm{~mL})$. The organic layer was dried over $\mathrm{Na}_{2} \mathrm{SO}_{4}$ and the solvent evaporated under reduced pressure to give 2 as a brownish solid in $88.5 \%$ yield (62.8mg). TLC (AcOEt) Rf: $0.21 ;{ }^{1} \mathbf{H}$ NMR ( $\left.\mathbf{C D C l}_{3}, \mathbf{3 0 0 M H z}\right) \boldsymbol{\delta}(\mathbf{p p m}): 7.23(\mathrm{dd}, J=1.8,0.8 \mathrm{~Hz}, 1 \mathrm{H}), 6.21(\mathrm{dd}, J=3.1,1.9 \mathrm{~Hz}, 1 \mathrm{H}), 5.59$ (br s, 1H), 5.59 (br s, 1H), 3.97 (dd, $J=5.2,2.6 \mathrm{~Hz}, 1 \mathrm{H}), 2.93(\mathrm{t}, J=7.5 \mathrm{~Hz}, 2 \mathrm{H}), 2.46(\mathrm{t}, J=7.5 \mathrm{~Hz}, 2 \mathrm{H}), 2.15$ (t, $J=2.6 \mathrm{~Hz}, 1 \mathrm{H}) ;{ }^{13} \mathbf{C} \mathbf{N M R}\left(\mathbf{C D C l}_{3}, \mathbf{7 5} \mathbf{M H z}\right) \boldsymbol{\delta}(\mathbf{p p m}): 171.3,154.1,141.3,110.3,105.6,79.4,71.6,34.7,29.2$, 23.8; MS (ESI, MeOH): $m / z$ calcd for $\mathrm{C}_{10} \mathrm{H}_{11} \mathrm{NO}_{2}[\mathrm{M}]: 177.07898$, found: $178.2[\mathrm{M}+\mathrm{H}]^{+}, 377.2[2 \mathrm{M}+\mathrm{Na}]^{+}, 176.1$ [M-H] ; HR-MS (ESI, MeOH): $m / z$ calcd for $\left[\mathrm{C}_{10} \mathrm{H}_{12} \mathrm{NO}_{2} \mathrm{Na}\right]^{+}: 178.08626$, found: 178.0859 . 
Furan-PNA: a mildly inducible irreversible interstrand crosslinking system targeting single and double stranded DNA - Electronic Supporting Information

Fmoc-PNA-Furan-O ${ }^{t}$ Bu (3): in a round bottom flask $1(64.7 \mathrm{mg}, 0.462 \mathrm{mmol}$, 2eq) and DhBtOH $(75.4 \mathrm{mg}$, $0.462 \mathrm{mmol}, 2 \mathrm{eq})$ were dissolved in $2 \mathrm{~mL} \mathrm{DMF}$ and cooled to $0^{\circ} \mathrm{C}$ with an ice bath. $\mathrm{EDC} \cdot \mathrm{HCl}(88.5 \mathrm{mg}, 0.462 \mathrm{mmol}$, 2eq) and DIPEA $(114.5 \mu \mathrm{L}, 0.693 \mathrm{mmol}, 3 \mathrm{eq})$ were then added and the mixture was left to react 10 minutes at $0^{\circ} \mathrm{C}$ and subsequently 10 minutes at r.t.. Finally, Fmoc-PNA-backbone- ${ }^{t} \mathrm{Bu}(100.6 \mathrm{mg}, 0.232 \mathrm{mmol}$, 1eq) was added and the mixture was left to react for $4 \mathrm{~h}$. The reaction was then diluted with AcOEt $(100 \mathrm{~mL})$ and washed with $0.1 \mathrm{M}$ $\mathrm{HCl}(2 \times 100 \mathrm{~mL})$, saturated aq. $\mathrm{NaHCO}_{3}(2 \times 100 \mathrm{~mL})$ and brine $(100 \mathrm{~mL})$. The organic layer was dried over $\mathrm{Na}_{2} \mathrm{SO}_{4}$ and the solvent evaporated under reduced pressure. The crude was then purified through percolation over silica (elution from hexane to hexane:AcOEt 1:1) to obtain 3 as a foamy solid in 85.3\% yield (102.7mg). TLC (AcOEt) Rf: $0.64 ;{ }^{1} \mathbf{H}$ NMR $\left(\mathbf{C D C l}_{3}, \mathbf{3 0 0 M H z}\right.$, major rotamer) $\boldsymbol{\delta}(\mathbf{p p m}): 7.69(\mathrm{~d}, \mathrm{~J}=7.5 \mathrm{~Hz}, 2 \mathrm{H}), 7.50(\mathrm{~d}, \mathrm{~J}=7.1 \mathrm{~Hz}$, 2H), $7.32(\mathrm{t}, \mathrm{J}=7.2 \mathrm{~Hz}, 2 \mathrm{H}), 7.23(\mathrm{t}, \mathrm{J}=7.2 \mathrm{~Hz}, 2 \mathrm{H}), 7.13(\mathrm{~s}, 1 \mathrm{H}), 6.12(\mathrm{br} \mathrm{s}, 1 \mathrm{H}), 5.95-5.80(\mathrm{~m}, 2 \mathrm{H}), 4.28(\mathrm{~d}, \mathrm{~J}$ $=7.0 \mathrm{~Hz}, 2 \mathrm{H}), 4.14(\mathrm{t}, \mathrm{J}=6.8 \mathrm{~Hz}, 1 \mathrm{H}), 3.84(\mathrm{~s}, 2 \mathrm{H}), 3.42(\mathrm{t}, \mathrm{J}=5.8 \mathrm{~Hz}, 2 \mathrm{H}), 3.30(\mathrm{t}, \mathrm{J}=5.5 \mathrm{~Hz}, 2 \mathrm{H}), 2.87(\mathrm{t}, \mathrm{J}=$ $7.0 \mathrm{~Hz}, 2 \mathrm{H}), 2.60(\mathrm{t}, \mathrm{J}=7.0 \mathrm{~Hz}, 2 \mathrm{H}),, 1.40(\mathrm{~s}, 9 \mathrm{H}) ;{ }^{13} \mathbf{C} \mathbf{~ N M R}\left(\mathbf{C D C l}_{3}, \mathbf{7 5} \mathbf{M H z}\right.$, major rotamer) $\boldsymbol{\delta}(\mathbf{p p m}): \mathbf{1 7 1 . 3}$, 168.7, 155.6, 153.6, 142.8, 140.3, 126.6, 126.05, 124.1, 118.9, 110.6, 109.2, 104.3, 81.3, 66.0, 48.9, 48.3, 46.2, 38.4, 30.3, 27.0, 22.5; MS (ESI, MeOH): $\mathrm{m} / z$ calcd for $\mathrm{C}_{30} \mathrm{H}_{34} \mathrm{~N}_{2} \mathrm{O}_{6}[\mathrm{M}]: 518.24169$, found: 463.2 [M-ibutene+H $]^{+}, 519.4[\mathrm{M}+\mathrm{H}]^{+}, 541.3[\mathrm{M}+\mathrm{Na}]^{+}, 553.2[\mathrm{M}+\mathrm{Cl}]^{-}$; HR-MS (ESI, MeOH): $m / z$ calcd for $\left[\mathrm{C}_{30} \mathrm{H}_{35} \mathrm{~N}_{2} \mathrm{O}_{6}\right]^{+}$: 519.24896, found: 519.2487 .

Fmoc-PNA-Furan-OH (4): in a round bottom flask 3 (92.9mg, 0.179mmol, 1eq) was dissolved in 20mL DCM and cooled to $0^{\circ} \mathrm{C}$ with an ice bath. To this mixture $5 \mathrm{~mL}$ TFA was added dropwise and the solution was left to react for $1 \mathrm{~h}$ at $0^{\circ} \mathrm{C}$ and then $2 \mathrm{~h}$ at r.t.. When conversion was complete the solvents were evaporated in presence of $\mathrm{MeOH}$ (20mL, color change from deep blue to yellow/green). Remaining TFA was finally co-evaporated with $\mathrm{CHCl}_{3}$ to obtain 4 as a brownish solid in a quantitative yield. TLC (hexane:AcOEt 1:1) Rf: 0.07; ${ }^{1} \mathbf{H}$ NMR (DMSO-d ${ }^{6}, 300 \mathrm{MHz}$, major rotamer) $\boldsymbol{\delta}(\mathbf{p p m}): 12.59(\mathrm{~s}, 1 \mathrm{H}), 7.89(\mathrm{~d}, J=7.5 \mathrm{~Hz}, 2 \mathrm{H}), 7.65(\mathrm{~d}, J=8.0 \mathrm{~Hz}, 2 \mathrm{H})$, $7.50-7.23(\mathrm{~m}, 5 \mathrm{H}), 6.35-6.30(\mathrm{~m}, 1 \mathrm{H}), 6.11-6.02(\mathrm{~m}, 1 \mathrm{H}), 4.29(\mathrm{~d}, J=6.3 \mathrm{~Hz}, 2 \mathrm{H}), 4.19(\mathrm{t}, J=7.4 \mathrm{~Hz}, 1 \mathrm{H})$, $3.94(\mathrm{~s}, 2 \mathrm{H}), 3.46-3.22(\mathrm{~m}, 2 \mathrm{H}), 3.20-3.05(\mathrm{~m}, 2 \mathrm{H}), 2.82-2.75(\mathrm{~m}, 2 \mathrm{H}), 2.70-2.60(\mathrm{~m}, 2 \mathrm{H}) ;{ }^{13} \mathbf{C} \mathbf{N M R}$ (DMSO-d $\mathbf{6}^{\mathbf{6}}$ 75MHz, major rotamer) $\boldsymbol{\delta}(\mathbf{p p m}):$ 171.6, 170.9, 156.2, 154.7, 143.8, 140.7, 127.6, 127.0, 125.0, 120.1, 110.3, 105.0, 65.4, 47.3 (x2), 46.7, 39.1, 30.0, 23.1; MS (ESI, MeOH): $m / z$ calcd for $\mathrm{C}_{26} \mathrm{H}_{26} \mathrm{~N}_{2} \mathrm{O}_{6}$ [M]: 462.17909, found: $463.2[\mathrm{M}+\mathrm{H}]^{+}, 461.2[\mathrm{M}-\mathrm{H}]^{-}, 923.4$ [2M-H]; HR-MS (ESI, MeOH): $\mathrm{m} / \mathrm{z}$ calcd for $\left[\mathrm{C}_{26} \mathrm{H}_{27} \mathrm{~N}_{2} \mathrm{O}_{6}\right]^{+}: 463.18636$, found: 463.1863 .

Fmoc-PNA-N ${ }_{3}-\mathbf{O}^{t} \mathbf{B u}(5)$ : in a round bottom flask 2-azidoacetic acid $(38.28 \mu \mathrm{L}, 0.511 \mathrm{mmol}, 2 \mathrm{eq})$ and $\mathrm{DhBtOH}$ (83.4mg, $0.511 \mathrm{mmol}, 2 \mathrm{eq})$ were dissolved in $2 \mathrm{~mL}$ DMF and cooled to $0^{\circ} \mathrm{C}$ with an ice bath. EDC $\cdot \mathrm{HCl}(98.0 \mathrm{mg}$, $0.511 \mathrm{mmol}, 2 \mathrm{eq})$ and DIPEA $(126.8 \mu \mathrm{L}, 0.767 \mathrm{mmol}, 3 \mathrm{eq})$ were added and the mixture was left to react 10 minutes at $0^{\circ} \mathrm{C}$ and then 10 minutes at r.t.. Finally, Fmoc-PNA-backbone- $\mathrm{O}^{t} \mathrm{Bu}(110.7 \mathrm{mg}, 0.256 \mathrm{mmol}, 1 \mathrm{eq})$ was added and the mixture was left to react for $3 \mathrm{~h}$. The reaction was then diluted with AcOEt $(100 \mathrm{~mL})$ and washed with $0.1 \mathrm{M}$ $\mathrm{HCl}(2 \times 100 \mathrm{~mL})$, saturated aq. $\mathrm{NaHCO}_{3}(2 \times 100 \mathrm{~mL})$ and brine $(100 \mathrm{~mL})$. The organic layer was dried over $\mathrm{Na}_{2} \mathrm{SO}_{4}$ and the solvent evaporated under reduced pressure. The crude was then purified through percolation over silica (elution from hexane:AcOEt 9:1 to hexane:AcOEt 1:1) to obtain 5 as a yellowish oil in $97.8 \%$ yield (119.9mg). TLC (AcOEt) Rf: 0.63; ${ }^{1} \mathbf{H}$ NMR $\left(\mathbf{C D C l}_{3}, \mathbf{3 0 0 M H z}\right.$, major rotamer) $\boldsymbol{\delta}(\mathbf{p p m}): 7.70(\mathrm{~d}, J=7.4 \mathrm{~Hz}, 2 \mathrm{H}), 7.52(\mathrm{~d}$, $J=7.5 \mathrm{~Hz}, 2 \mathrm{H}), 7.34(\mathrm{t}, J=7.4 \mathrm{~Hz}, 2 \mathrm{H}), 7.25(\mathrm{t}, J=7.4 \mathrm{~Hz}, 2 \mathrm{H}), 5.74(\mathrm{br} \mathrm{s}, 1 \mathrm{H}), 4.32(\mathrm{~d}, J=7.0 \mathrm{~Hz}, 2 \mathrm{H}), 4.15(\mathrm{t}$, $J=6.8 \mathrm{~Hz}, 1 \mathrm{H}), 3.88(\mathrm{~s}, 2 \mathrm{H}), 3.85(\mathrm{~s}, 2 \mathrm{H}), 3.40-3.25(\mathrm{~m}, 4 \mathrm{H}), 1.41(\mathrm{~s}, 9 \mathrm{H}) ;{ }^{13} \mathbf{C} \mathbf{N M R}\left(\mathbf{C D C l}_{\mathbf{3}}, \mathbf{7 5} \mathbf{M H z}\right.$, major rotamer) $\boldsymbol{\delta}(\mathbf{p p m}): 169.0,168.1,156.6,143.8,141.3,127.8,127.1,125.0,120.0,82.7,67.0,50.0,49.8,48.6,47.2$, 39.2, 28.0; MS (ESI, MeOH): $\mathrm{m} / z$ calcd for $\mathrm{C}_{25} \mathrm{H}_{29} \mathrm{~N}_{5} \mathrm{O}_{5}$ [M]: 479.21687, found: 424.2 [M-i-butene+H] ${ }^{+}, 502.2$ $[\mathrm{M}+\mathrm{Na}]^{+}, 514.1[\mathrm{M}+\mathrm{Cl}]$; HR-MS (ESI, MeOH): $\mathrm{m} / z$ calcd for $\left[\mathrm{C}_{25} \mathrm{H}_{29} \mathrm{~N}_{5} \mathrm{O}_{5} \mathrm{Na}\right]^{+}: 502.20609$, found: 502.2052. 
Furan-PNA: a mildly inducible irreversible interstrand crosslinking system targeting single and double stranded DNA - Electronic Supporting Information

Fmoc-PNA-N ${ }_{3}-\mathbf{O H}(6)$ : in a round bottom flask $5(113.0 \mathrm{mg}, 0.236 \mathrm{mmol}$, 1eq) was dissolved in 10mL DCM and cooled to $0^{\circ} \mathrm{C}$ with an ice bath. To this mixture $4 \mathrm{~mL}$ TFA was added dropwise and the solution was left to react for 5 minutes at $0^{\circ} \mathrm{C}$ and subsequently 30 minutes at r.t. When conversion was complete the solvents were evaporated in presence of $\mathrm{MeOH}(10 \mathrm{~mL})$. Remaining TFA was finally co-evaporated with $\mathrm{CHCl}_{3}$ to obtain $\mathbf{6}$ as a yellowish solid in a quantitative yield. TLC (AcOEt) Rf: 0.50; ${ }^{\mathbf{H}} \mathrm{H}$ NMR (DMSO-d $\mathbf{6}^{\mathbf{6}}, \mathbf{3 0 0 M H z}$, major rotamer) $\boldsymbol{\delta}(\mathbf{p p m}): 12.73(\mathrm{~s}, 1 \mathrm{H}), 7.89(\mathrm{~d}, J=7.4 \mathrm{~Hz}, 2 \mathrm{H}), 7.67(\mathrm{~d}, J=7.4 \mathrm{~Hz}, 2 \mathrm{H}), 7.44-7.27(\mathrm{~m}, 5 \mathrm{H}), 4.31(\mathrm{t}, J=7.6 \mathrm{~Hz}$, 2H), $4.22(\mathrm{~d}, J=7.6 \mathrm{~Hz}, 1 \mathrm{H}), 4.16(\mathrm{~s}, 2 \mathrm{H}), 3.96(\mathrm{~s}, 2 \mathrm{H}), 3.38-3.23(\mathrm{~m}, 2 \mathrm{H}), 3.22-3.05(\mathrm{~m}, 2 \mathrm{H}) . ;{ }^{13} \mathbf{C} \mathbf{~ N M R}$ (DMSO-d $^{6}$, 75MHz, major rotamer) $\boldsymbol{\delta}(\mathbf{p p m}):$ 170.4, 167.9, 156.3, 143.8, 140.7, 127.6, 127.0, 125.1, 120.1, 65.4, 49.5, 49.1, 46.7, 45.7,38.8; MS (ESI, MeOH): $m / z$ calcd for $\mathrm{C}_{21} \mathrm{H}_{21} \mathrm{~N}_{5} \mathrm{O}_{5}$ [M]: 423.15427, found: $424.2[\mathrm{M}+\mathrm{H}]^{+}$, 422.1 [M-H]', 845.2 [2M-H]; HR-MS (ESI, MeOH): $\mathrm{m} / z$ calcd for $\left[\mathrm{C}_{21} \mathrm{H}_{22} \mathrm{~N}_{5} \mathrm{O}_{5}\right]^{+}:$424.16155, found: 424.1610 .

PNA synthesis: the synthesis of all the PNAs was performed with standard Fmoc-based manual synthesis protocol using Fmoc-PNA-T(N)-OH, 4 and $\mathbf{6}$ in addition to standard monomers, on a Rink amide ChemMatrix resin loaded with Fmoc-Gly-OH as first monomer $(0.2 \mathrm{mmol} / \mathrm{g})$, using HBTU/DIPEA as activating mixture. Cleavage of the resin was performed using a TFA/m-cresol 9:1 solution for all the PNA strands except for PNA F which was cleaved with a TFA/m-cresol/tioanisole 8:1:1 solution. The cleavage step was carried out for $1 \mathrm{~h}$, twice.

Comparison of cleavage cocktails for the protection of furan: few beads (about $1 \mathrm{mg}$ ) of a test resin containing a furan moiety (Fmoc-AFGATCT-Gly-Res) were placed in an eppendorf tube, then $50 \mu \mathrm{L}$ of cleavage cocktail (aTFA/m-cresol 9:1, b- TFA/m-cresol/tioanisole 8:1:1, c- TFA/TIS/m-cresol 8:1:1, d- TFA/TIS/tioanisole 8:1:1) was added and left to react. After 1h30' ethyl ether was added and the precipitate was collected by centrifugation. The crudes were then analyzed by HPLC-UV and the identity of the peaks was confirmed by purification and MALDI analysis.

General protocol for click reaction: different solutions were prepared: $200 \mathrm{mM}$ solution of $\mathbf{2}$ in $\mathrm{MeOH}, 200$ $\mathrm{mM}$ solution of copper sulfate in $\mathrm{H}_{2} \mathrm{O}, 200 \mathrm{mM}$ solution of sodium ascorbate in $\mathrm{H}_{2} \mathrm{O}$. Reaction was carried out with a final PNA concentration (from crude PNA) of $2 \mathrm{mM}$ or $5 \mathrm{mM}$ using a molar ratio alkyne/ascorbate/Cu(II) of 2:4:2. The mixture was then left to react for $2 \mathrm{~h}$ before the purification (no significant variation of the HPLC profile observed between 15 minutes and $1 \mathrm{~h}$ ).

UPLC-MS characterization: PNA T: $\mathrm{R}_{\mathrm{t}}: 2.90 \mathrm{~min}, \mathrm{MW}: 3090.98, \mathrm{~m} / \mathrm{z}$ found: $1031.4[\mathrm{M}+3 \mathrm{H}]^{3+}, 773.6$ $[\mathrm{M}+4 \mathrm{H}]^{4+}, 619.2[\mathrm{M}+5 \mathrm{H}]^{5+}, 516.1[\mathrm{M}+6 \mathrm{H}]^{6+}$; PNA T(f): $\mathrm{R}_{\mathrm{t}}: 3.19 \mathrm{~min}, \mathrm{MW}: 3351.23, \mathrm{~m} / \mathrm{z}$ found: 1187.3 $[\mathrm{M}+3 \mathrm{H}]^{3+}, 838.8[\mathrm{M}+4 \mathrm{H}]^{4+}, 671.2[\mathrm{M}+5 \mathrm{H}]^{5+}, 599.6[\mathrm{M}+6 \mathrm{H}]^{6+}$; PNA f: $\mathrm{R}_{\mathrm{t}}: 3.07 \mathrm{~min}, \mathrm{MW}: 3227.13, \mathrm{~m} / \mathrm{z}$ found: $1176.8[\mathrm{M}+3 \mathrm{H}]^{3+}, 807.8[\mathrm{M}+4 \mathrm{H}]^{4+}, 646.5[\mathrm{M}+5 \mathrm{H}]^{5+}, 538.9[\mathrm{M}+6 \mathrm{H}]^{6+}$; PNA F: $\mathrm{R}_{\mathrm{t}}: 3.13 \mathrm{~min}, \mathrm{MW}: 3089.00, \mathrm{~m} / \mathrm{z}$ found: $1030.8[\mathrm{M}+3 \mathrm{H}]^{3+}, 773.3[\mathrm{M}+4 \mathrm{H}]^{4+}, 618.8[\mathrm{M}+5 \mathrm{H}]^{5+}, 516.1[\mathrm{M}+6 \mathrm{H}]^{6+}$. 
Furan-PNA: a mildly inducible irreversible interstrand crosslinking system targeting single and double stranded DNA - Electronic Supporting Information

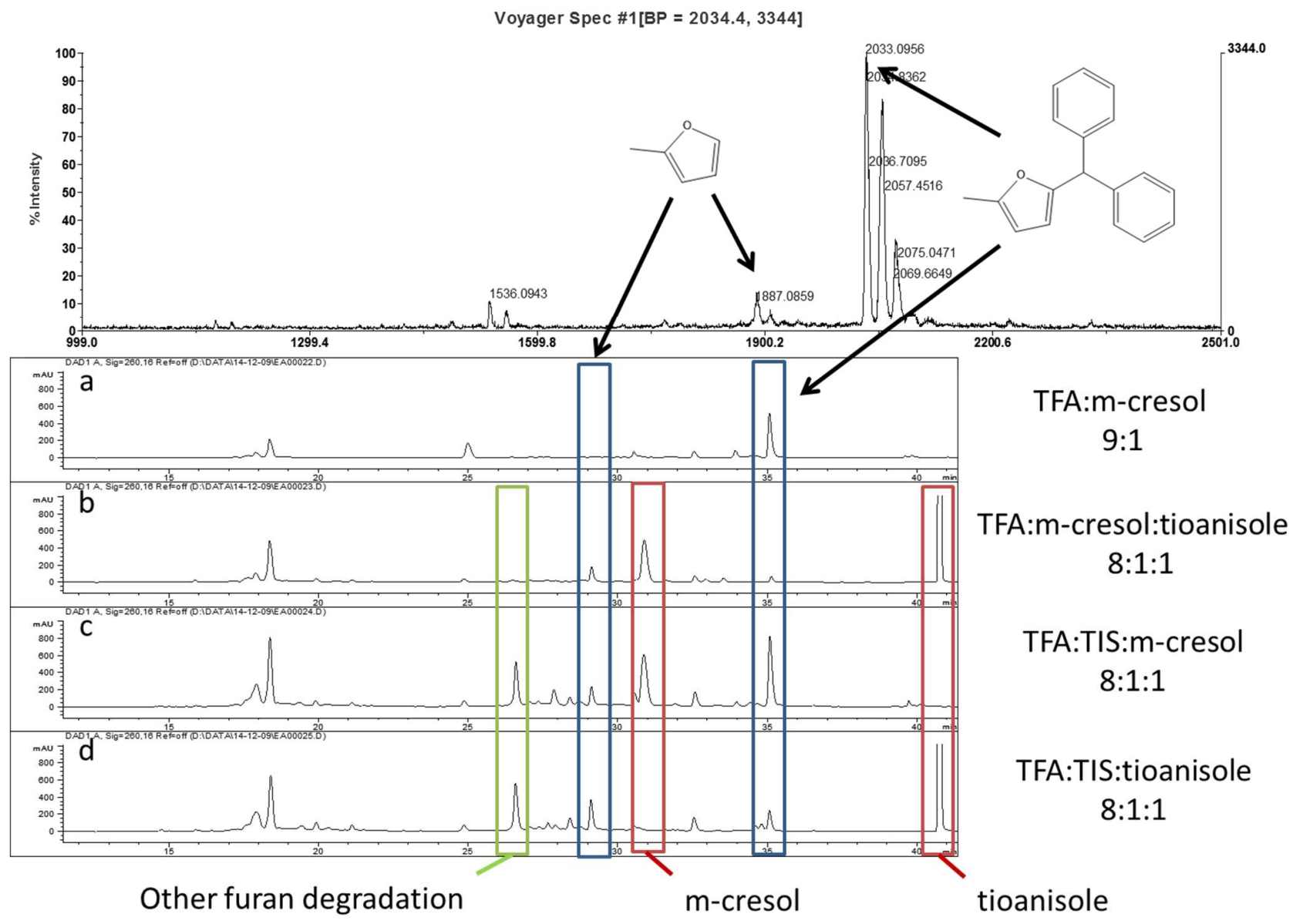

Fig. S1: MALDI spectrum of the crude from test a (top) and HPLC1-UV profiles of the crude obtained from the different cleavage cocktails.

Measurements of $\mathbf{T}_{\mathbf{m}}$ values: thermal denaturation profiles were measured by monitoring the absorbance at $260 \mathrm{~nm}$ from $18^{\circ} \mathrm{C}$ to $90^{\circ} \mathrm{C}$ and from $90^{\circ} \mathrm{C}$ to $18^{\circ} \mathrm{C}$ with a heating rate of $1{ }^{\circ} \mathrm{C} / \mathrm{min}$ and recording every $0.1^{\circ} \mathrm{C}(3$ cycles). Measurement condition: strand concentration $=5 \mu \mathrm{M}$ in $\mathrm{pH} 7.0$ PBS buffer $(100 \mathrm{mM} \mathrm{NaCl}, 10 \mathrm{mM}$ $\mathrm{NaH}_{2} \mathrm{PO}_{4}$ ). Melting temperatures were calculated from the first derivative of the heating curves using the Cary 300 Bio software.

Table S1: melting temperature $\left({ }^{\circ} \mathrm{C}\right)$ of the PNA:DNA complexes; PNA X: Ac-GGGCAXGATCT-Gly-NH 2, DNA Y: 5 'AGATCYTGCCC-3', DNA as: 5'-GGGCATGATCT-3'. Number inside parentheses indicate the hysteresis of the processes, i.e. the differences between the melting and annealing temperature, obtained by the heating and cooling curves respectively.

\begin{tabular}{|c|c|c|c|c|c|}
\hline \multicolumn{2}{|c|}{} & \multicolumn{4}{|c|}{ DNA } \\
\cline { 3 - 6 } \multicolumn{2}{|c|}{} & A & C & G & T \\
\hline \multirow{3}{*}{ PNA } & 0 & $68.94(4.78)$ & $49.97(4.10)$ & $55.44(3.63)$ & $56.84(4.21)$ \\
\cline { 2 - 6 } & $\mathrm{f}$ & $49.98(3.08)$ & $49.81(3.02)$ & $59.52(3.28)$ & $51.24(2.13)$ \\
\cline { 2 - 6 } & $\mathrm{T}(\mathrm{f})$ & $69.03(2.99)$ & $51.00(2.62)$ & $55.79(2.78)$ & $57.85(3.11)$ \\
\cline { 2 - 6 } & $\mathrm{F}$ & $47.37(2.98)$ & $47.21(3.28)$ & $47.96(3.18)$ & $47.22(3.60)$ \\
\hline & DNA T & $50.52(3.33)$ & $33.86(3.38)$ & & \\
\end{tabular}


Furan-PNA: a mildly inducible irreversible interstrand crosslinking system targeting single and double stranded DNA - Electronic Supporting Information

General protocol for crosslink reactions: a solution was prepared at $10 \mu \mathrm{M}$ concentration of each strand in PBS with a total volume of $50 \mu \mathrm{L}$ solution. The complexes were slowly annealed from $90^{\circ}$ to room temperature (in about $2 \mathrm{~h}$ ). During the crosslink reaction, temperature was kept constant in an Eppendorf thermomixer comfort at $25^{\circ} \mathrm{C}$ (unless otherwise mentioned). A stock solution of NBS $(0.5 \mathrm{nmol} / 2 \mu \mathrm{L})$ was freshly prepared and to start the reaction, 1 equiv $(=0.5 \mathrm{nmol})$ of NBS was added. This was repeated every 15 min until 4 equiv of NBS were added. The reactions were monitored by HPLC2.

For strand displacement experiments dsDNA was annealed at $20 \mu \mathrm{M}$ probe concentration, then PNA was added to a final probe concentration of $10 \mu \mathrm{M}$, the solution was then left to equilibrate at controlled temperature $\left(25^{\circ} \mathrm{C}\right.$ or $37^{\circ} \mathrm{C}$ ) for 3 hours.

General protocol for PAGE: a 20\% polyacrylamide gel (acrylamide:bisacrylamide 19:1) for short oligonucleotide probe, or a 16\% polyacrylamide gel (acrylamide:bisacrylamide 37.5:1) for long oligonucleotide probes, were prepared in 1x Tris-Borat-EDTA (TBE) buffer containing $7 \mathrm{M}$ urea. The temperature of the gel was stabilized with a Julabo $\mathrm{F} 12$ at $25^{\circ} \mathrm{C}$. The power supply used for gel electrophoresis was a consort EV202 and a voltage of $260 \mathrm{~V}$ was used to run the gels. Gels were stained with GelRed (VWR) or SYBR gold (Thermo Fisher Scientific, Life Technologies) and pictures were taken with an Autochemi imaging system (UVP). $4 \mu \mathrm{L}$ of the crosslink solution $(10 \mu \mathrm{M})$ were mixed with $16 \mu \mathrm{L}$ formamide and from this mixture $8 \mu \mathrm{L}$ was loaded on the gel. 
Furan-PNA: a mildly inducible irreversible interstrand crosslinking system targeting single and double stranded DNA - Electronic Supporting Information

\section{PAGE experiments}

$$
\begin{gathered}
5^{\prime} \text { - AGA TCY TGC CC - }{ }^{\prime} \\
\mathrm{H}_{2} \mathrm{~N} \text {-Gly- TCT AGX ACG GG -AC }
\end{gathered}
$$
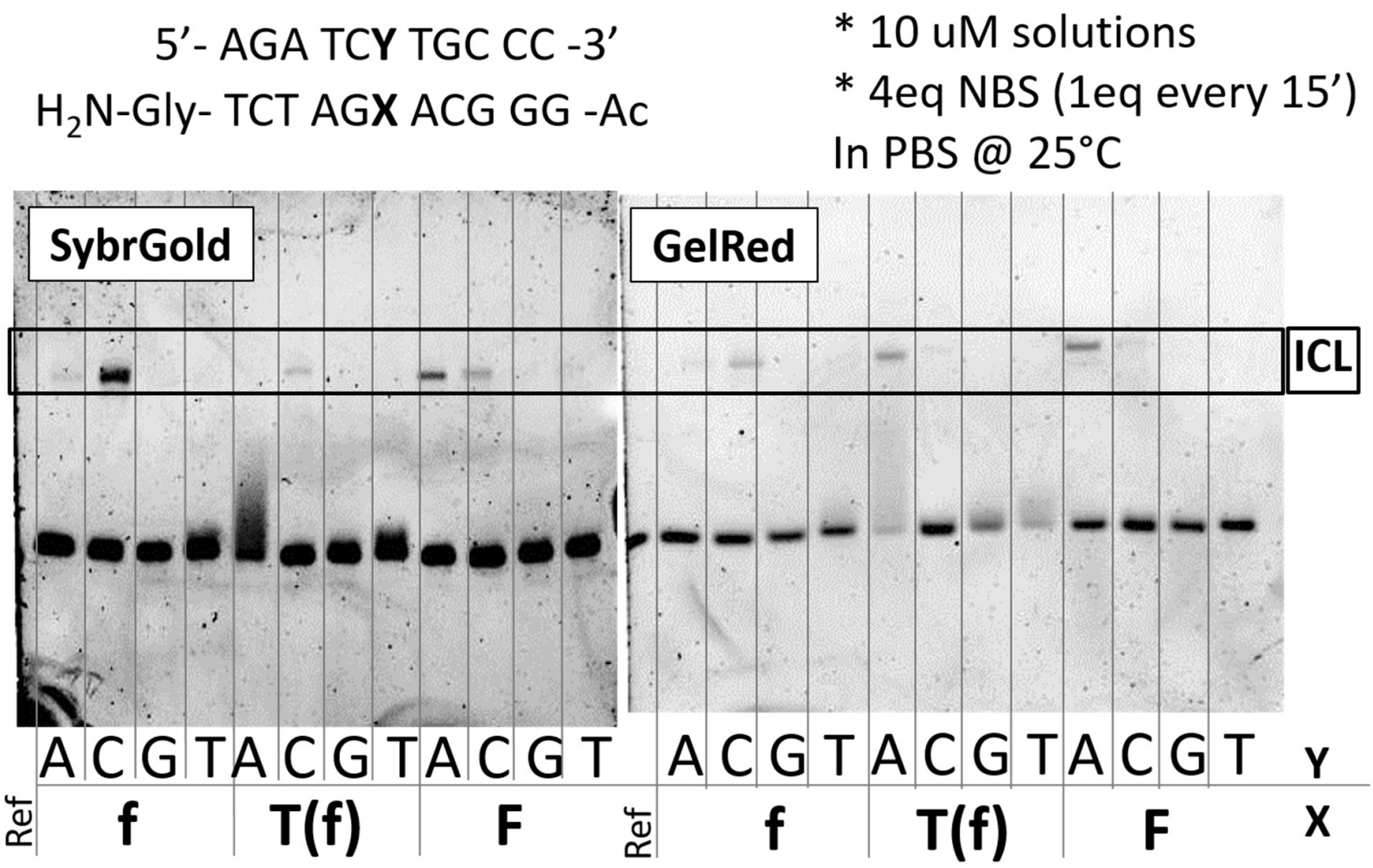

Fig. S2: full denaturing PAGE picture of the PNA:DNA crosslink experiment.

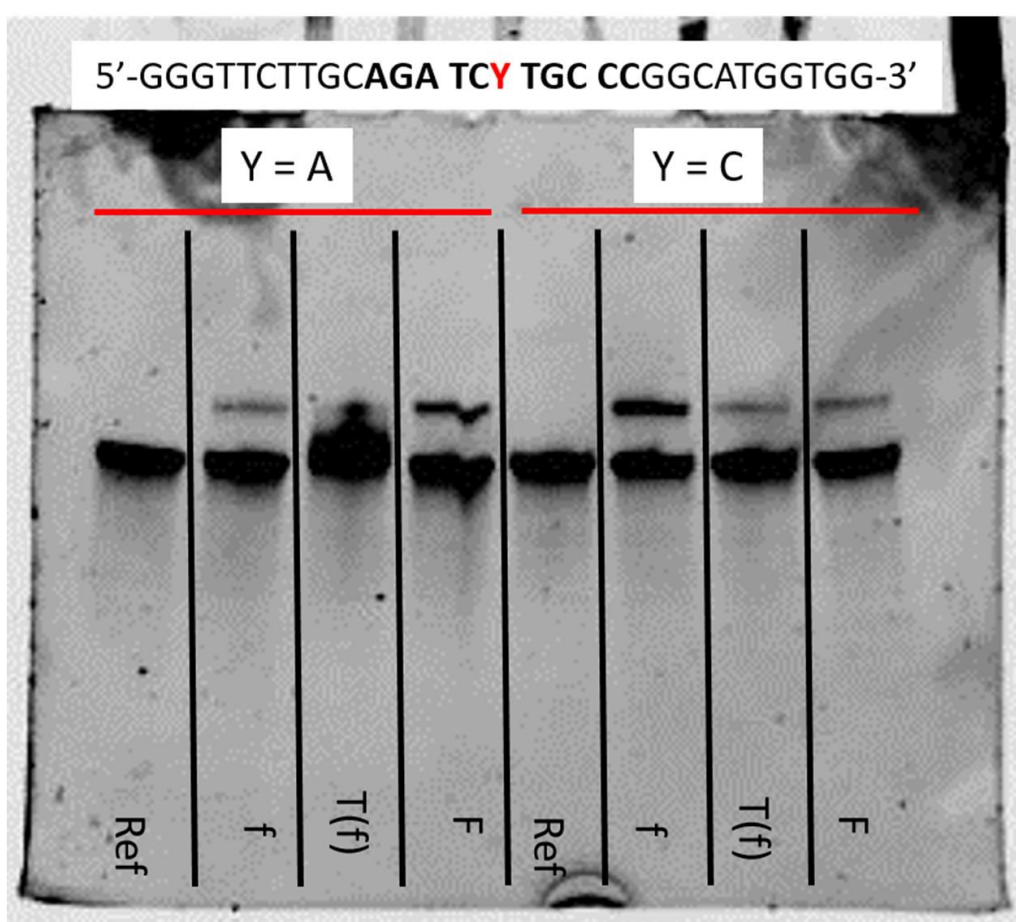

Fig. S3: full denaturing PAGE picture of the PNA:DNA crosslink experiment with long sequences. GelRed staining was used. 
Furan-PNA: a mildly inducible irreversible interstrand crosslinking system targeting single and double stranded DNA - Electronic Supporting Information

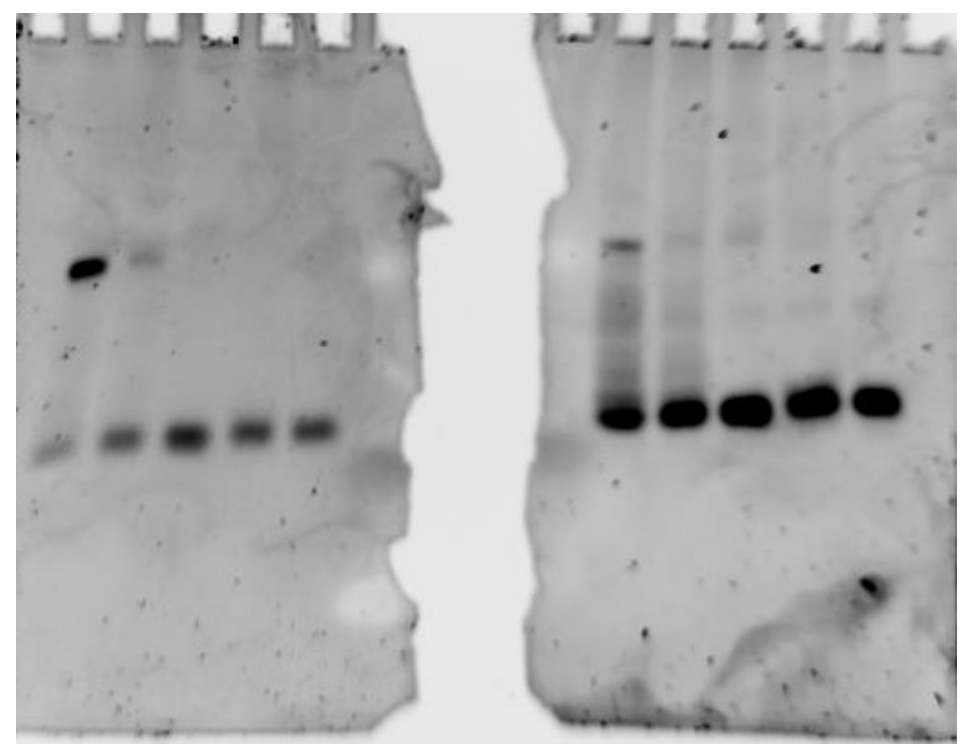

Fig. S4: denaturing PAGE experiments for PNA T(f) probe. Lanes (from left to right, each gel): 1) no NBS activation; 2) DNA A; 3) DNA C; 4) DNA G; 5) DNA T. Left gel was stained with GelRed, right gel was stained with SybrGold.

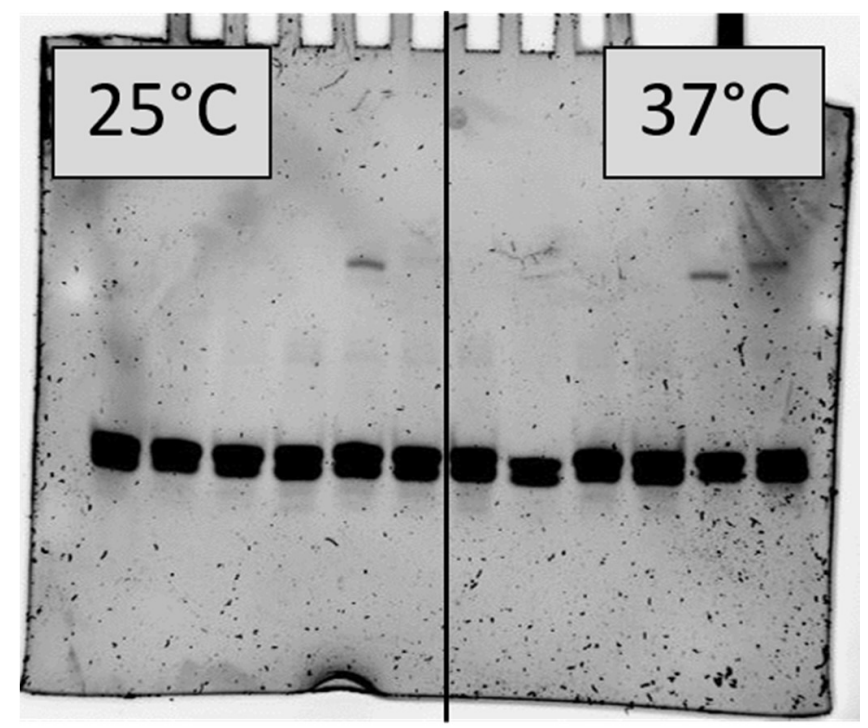

Fig. S5: full denaturing PAGE picture of the strand invasion crosslink experiments. Lanes (from left to right, each section): 1) Ref dsDNA A; 2) + PNA f; 3) + PNA F; 4) Ref dsDNA C; 5) + PNA f; 6) + PNA F. Stain: SybrGold. 
Furan-PNA: a mildly inducible irreversible interstrand crosslinking system targeting single and double stranded DNA - Electronic Supporting Information

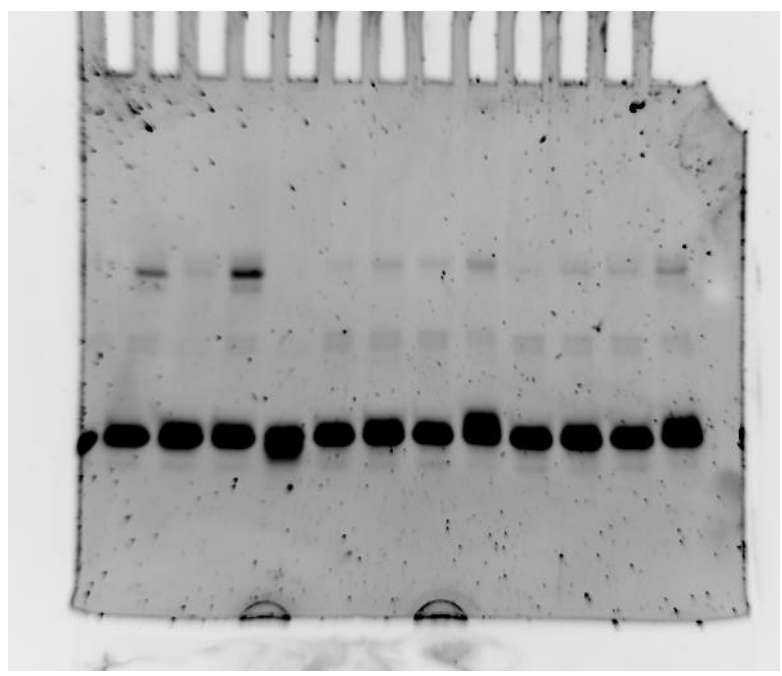

Fig. S6: effect of 2\% DMF in strand displacement crosslink experiments. Displacement was carried out at $37^{\circ} \mathrm{C}$ for $12 \mathrm{~h}$. Lanes (from left to right): 1) Ref; 2) PNA f + dsDNA A; 3) PNA f + dsDNA A + 2\% DMF; 4) PNA f + dsDNA C; 5) PNA f + dsDNA C + 2\% DMF; 6) PNA F + dsDNA A; 7) PNA F + dsDNA A + 2\% DMF; 8) PNA F + dsDNA F; 9) PNA F + dsDNA C + 2\% DMF; 10) PNA T(f) + dsDNA A; 11) PNA T(f) + dsDNA A + 2\% DMF; 12) PNA T(f) + dsDNA C; 13) PNA T(f) + dsDNA C $+2 \%$ DMF; 14$)$ color.

Table S2: densitometric evaluation of the ICL regions of the PAGE experiments shown in Fig. 3 and Fig. S2. ${ }^{a}$

\begin{tabular}{|c|c|c|c|c|c|c|c|c|}
\hline \multirow{2}{*}{ Lane } & \multirow{2}{*}{ PNA } & \multirow{2}{*}{ DNA } & \multicolumn{3}{|c|}{ SybrGold } & \multicolumn{3}{|c|}{ GelRed } \\
\hline & & & Mean & Min & Max & Mean & Min & Max \\
\hline 1 & \multicolumn{2}{|c|}{ Reflane } & 57.475 & 53 & 64 & 64.699 & 60 & 70 \\
\hline 2 & \multirow{4}{*}{$f$} & $A$ & 61.761 & 50 & 115 & 68.558 & 59 & 89 \\
\hline 3 & & $C$ & 99.507 & 52 & 189 & 81.486 & 64 & 103 \\
\hline 4 & & $T$ & 55.362 & 50 & 67 & 67.793 & 58 & 103 \\
\hline 5 & & G & 54.362 & 42 & 86 & 72.5 & 66 & 81 \\
\hline 6 & \multirow{4}{*}{$T(f)$} & $A$ & 54.489 & 43 & 64 & 93.341 & 68 & 140 \\
\hline 7 & & $C$ & 57.764 & 45 & 77 & 71.243 & 65 & 79 \\
\hline 8 & & $T$ & 56.565 & 37 & 205 & 67.935 & 64 & 91 \\
\hline 9 & & G & 56.036 & 48 & 97 & 69.96 & 67 & 76 \\
\hline 10 & \multirow{4}{*}{$F$} & $A$ & 74.38 & 52 & 120 & 105.46 & 72 & 168 \\
\hline 11 & & $C$ & 69.986 & 57 & 87 & 76.123 & 66 & 94 \\
\hline 12 & & $T$ & 60.264 & 49 & 104 & 65.159 & 62 & 69 \\
\hline 13 & & G & 61.312 & 53 & 71 & 62.406 & 55 & 66 \\
\hline
\end{tabular}

${ }^{a}$ As it cannot be assumed that the response factor for DNA and PNA-DNA is identical, the densitometric absolute values are given only for the ICL band region. 
Furan-PNA: a mildly inducible irreversible interstrand crosslinking system targeting single and double stranded DNA - Electronic Supporting Information

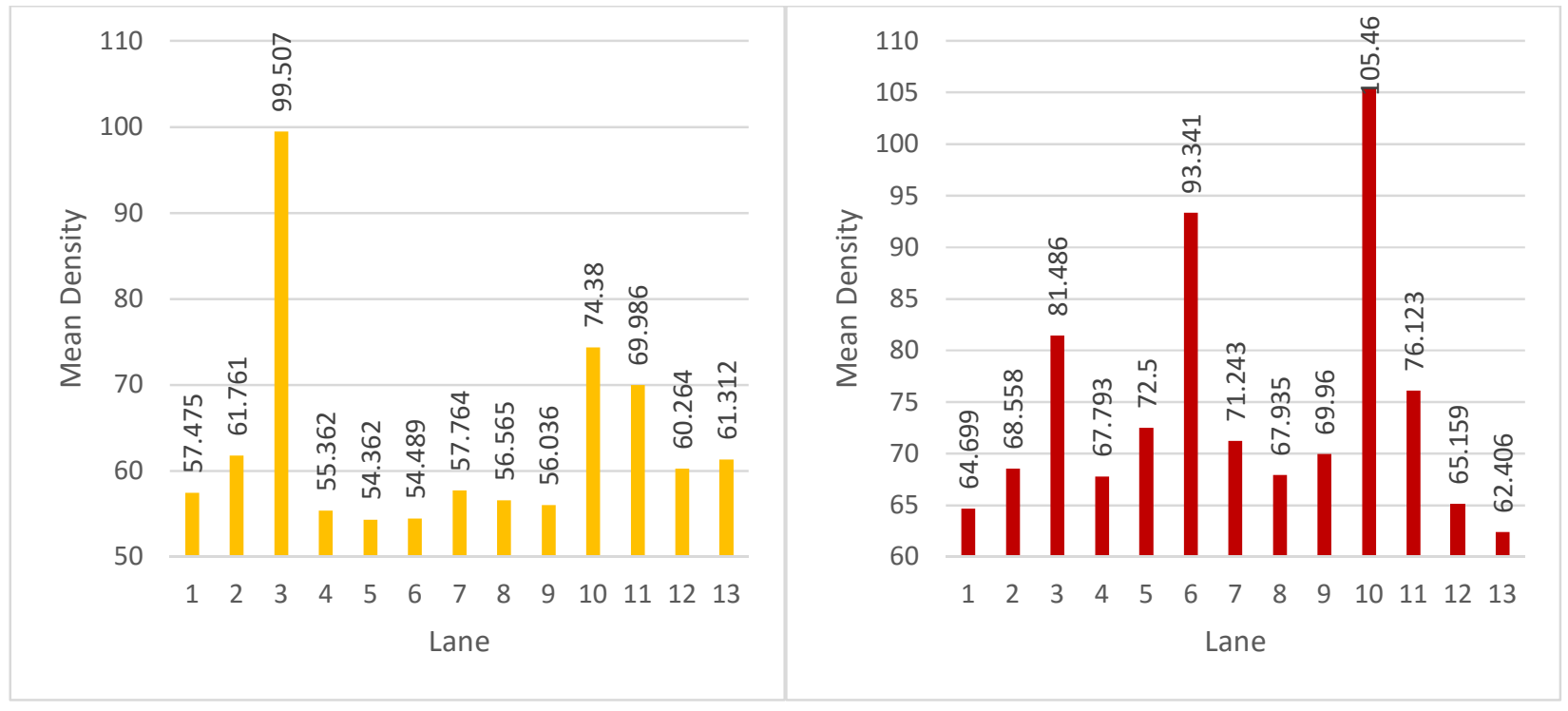

Fig. S7: histogram representation of the data presented in Table S2. Left: gel stained with SybrGold; right: gel stained with GelRed.

Table S3: densitometric evaluation of the ICL region of PAGE shown in Fig. 5 and Fig. S5. ${ }^{\text {a }}$

\begin{tabular}{|c|c|c|c|c|c|c|}
\hline Lane & PNA & DNA & Mean & Min & Max & \\
\hline 1 & \multicolumn{2}{|c|}{ Ref dsDNA A } & 80.486 & 51 & 102 & \multirow{6}{*}{$\begin{array}{l}\text { ज్ } \\
\text { กิ }\end{array}$} \\
\hline 2 & $f$ & \multirow{2}{*}{ dsDNA A } & 79.372 & 68 & 102 & \\
\hline 3 & $\mathrm{~F}$ & & 76.793 & 68 & 102 & \\
\hline 4 & Ref & DNA C & 65.128 & 51 & 102 & \\
\hline 5 & $f$ & \multirow{2}{*}{ dsDNA C } & 118.003 & 68 & 238 & \\
\hline 6 & $\mathrm{~F}$ & & 85.293 & 51 & 119 & \\
\hline 7 & \multicolumn{2}{|c|}{ Ref dsDNA A } & 76.559 & 51 & 153 & \multirow{6}{*}{$\begin{array}{l}\underbrace{w} \\
\text { గ }\end{array}$} \\
\hline 8 & $f$ & \multirow{2}{*}{ dsDNA A } & 87.462 & 68 & 170 & \\
\hline 9 & $\mathrm{~F}$ & & 83.417 & 68 & 153 & \\
\hline 10 & Ref & DNA C & 82.479 & 68 & 102 & \\
\hline 11 & $f$ & \multirow{2}{*}{ dsDNA C } & 135.062 & 85 & 187 & \\
\hline 12 & $\mathrm{~F}$ & & 175.803 & 136 & 238 & \\
\hline
\end{tabular}

${ }^{a}$ As it cannot be assumed that the response factor for DNA and PNA-DNA is identical, the densitometric absolute values are given only for the ICL. 
Furan-PNA: a mildly inducible irreversible interstrand crosslinking system targeting single and double stranded DNA - Electronic Supporting Information

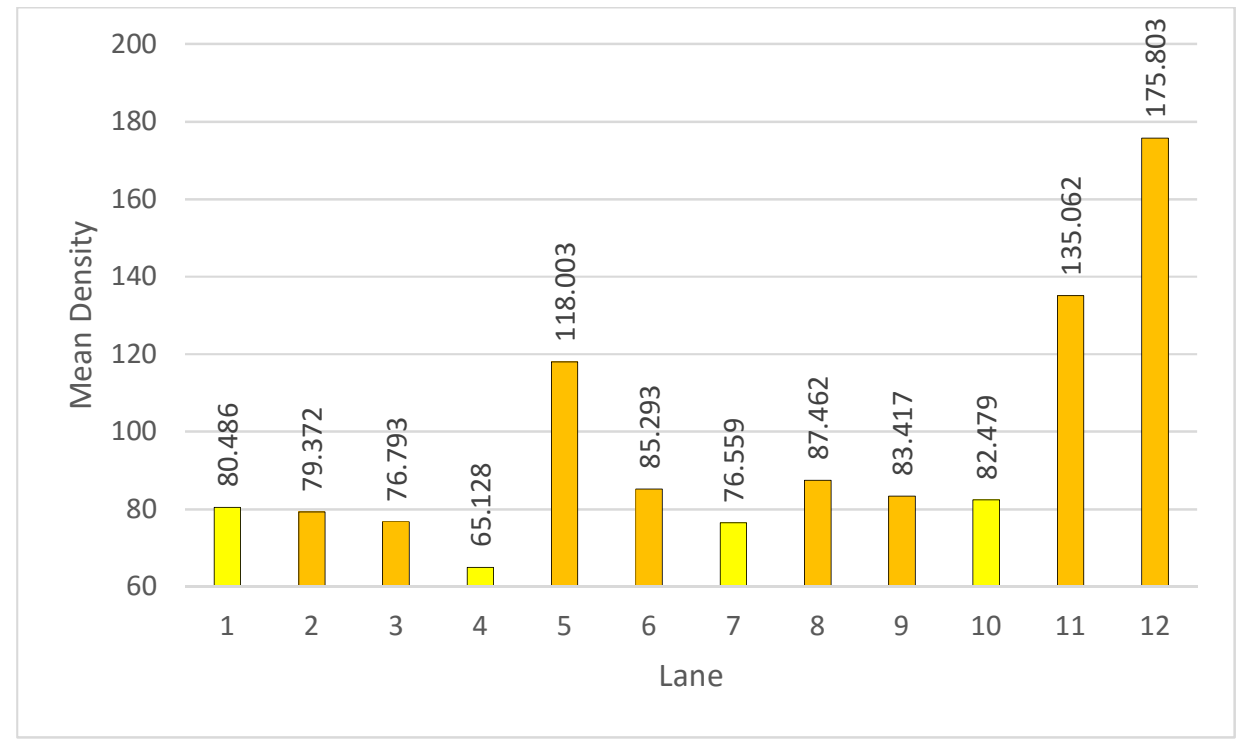

Fig. S8: histogram representation of the data presented in Table S3. Brighter bars correspond to reference lanes. 
Furan-PNA: a mildly inducible irreversible interstrand crosslinking system targeting single and double stranded DNA - Electronic Supporting Information

\section{Identification of the ICL products}

HPLC analysis of the ICL experiments was performed at 0 eq, 2eq and 4 eq of NBS added. Samples were prepared diluting $2 \mu \mathrm{L}$ of sample with $18 \mu \mathrm{L}$ of milliQ water, sample analysis was performed using HPLC2 conditions with $15 \mu \mathrm{L}$ of sample.

DNA and starting PNA retention times (respectivelly 10 minutes and 13 minutes regions) were determined by injection of reference samples. ICL was identified with the peaks appearing before the PNA after the addition of NBS. This peaks were isolated, freeze-dried, and the identity was analized with both PAGE experiments and MALDI-TOF analysis.

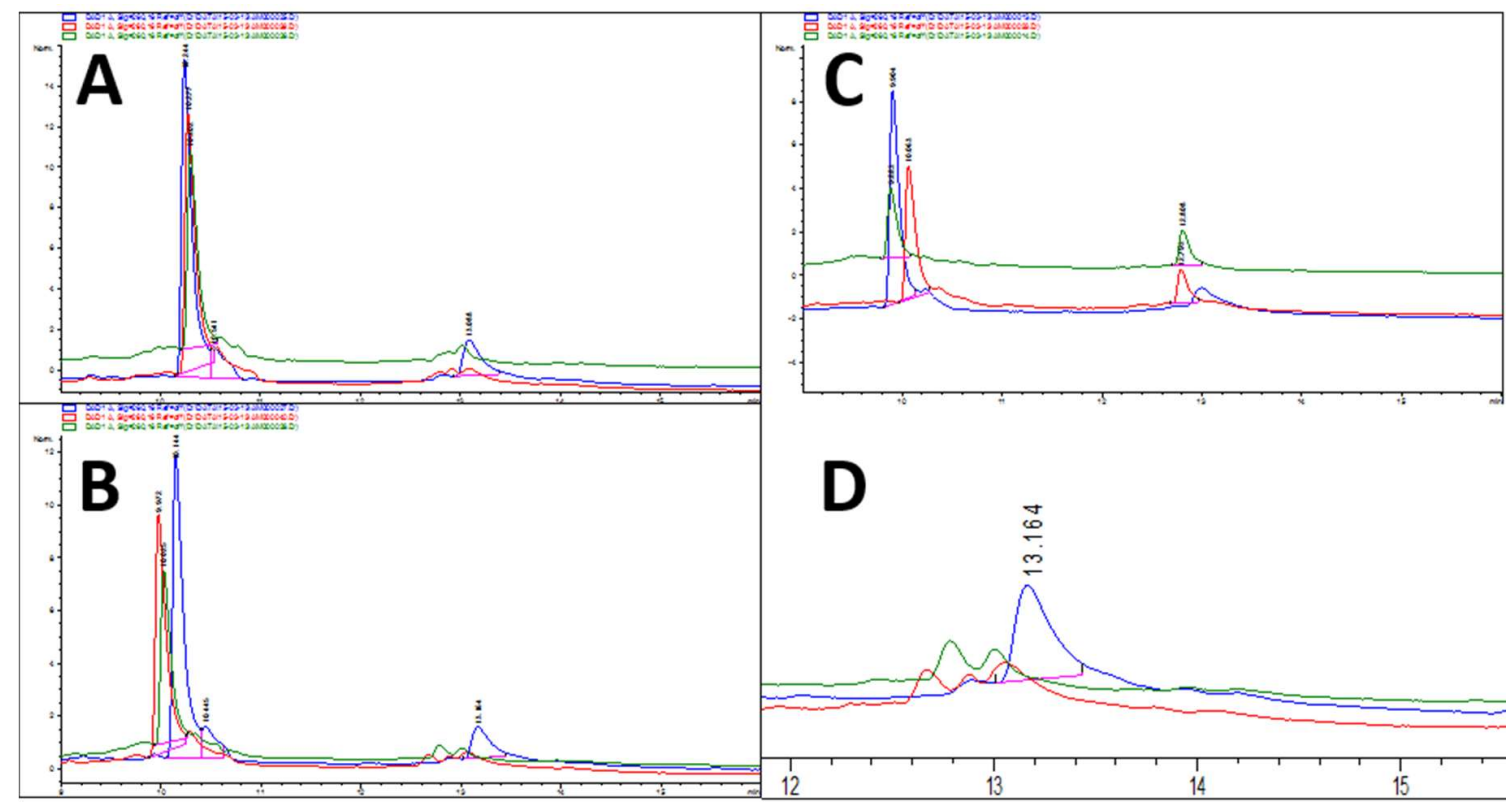

Fig. S9: example of HPLC trace of the ICL experiments at 0 eq (blue), 2 eq (red) and 4 eq NBS (green); (A) PNA F + DNA A, (B) PNA F + DNA C, (C) PNA f + DNA C, (D) zoom of the 12-15 minutes region of the PNA F + DNA C experiments.

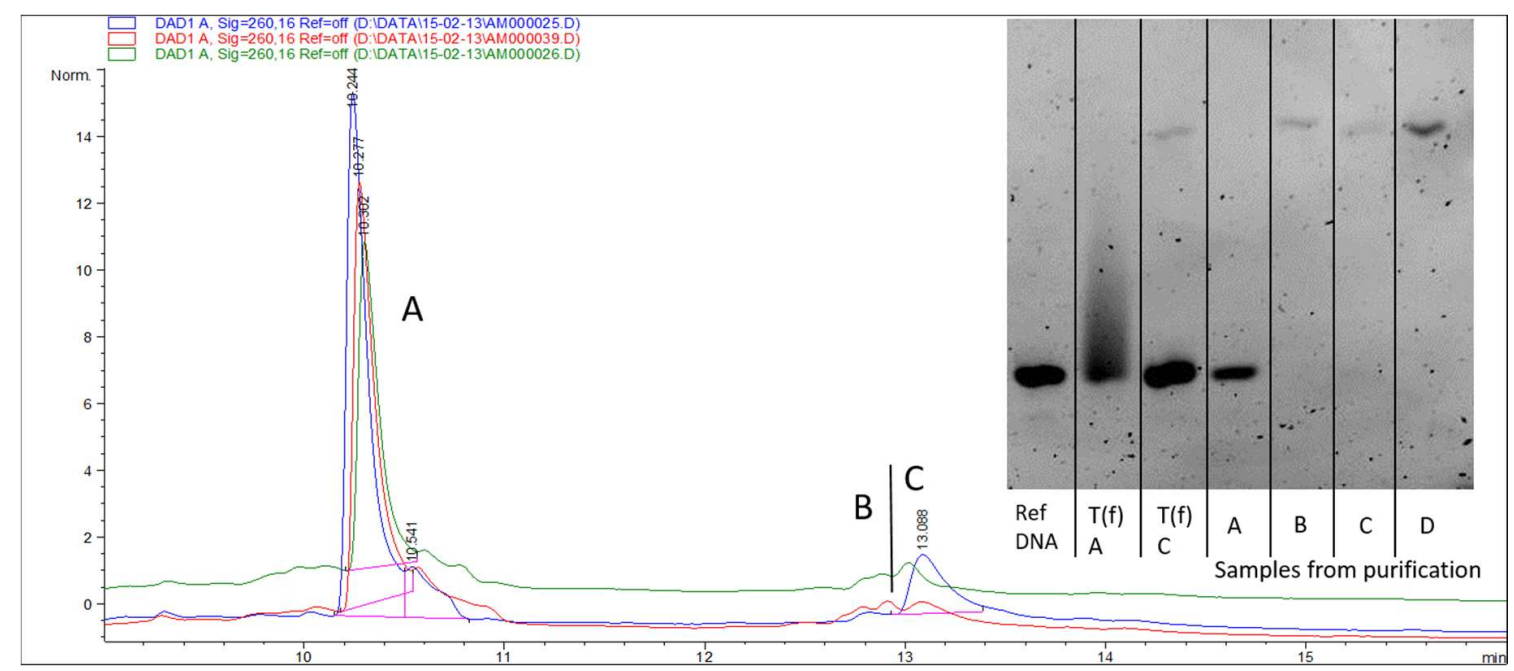

Fig. S10: HPLC trace of purified regions of a PNA F+ DNA A sample. In the insert the denaturing PAGE gel shift of the purified peaks in comparison with DNA A and PNA T(f) ICL experiments. Lane D in the gel corresponds to the B peak of a PNA F + DNA C ICL experiment. SybrGold staining was used. 
Furan-PNA: a mildly inducible irreversible interstrand crosslinking system targeting single and double stranded DNA - Electronic Supporting Information

For MALDI-TOF analysis, the collected products were directly dissolved in $2 \mu \mathrm{L}$ of matrix solution and spotted on the MALDI plate. Both DNA and PNA matrixes were tested, but signals were obtained only when PNA matrix was used (2,5-Dihydroxybenzoic acid). Examples of MALDI analysis are reported in Fig. S11, analysis of the MALDI peaks was carried out with a weighted average of the signals in order to reduce noise and to obtain the mean $\mathrm{m} / \mathrm{z}$ associated to the signal (Table $\mathrm{S} 4$ ).
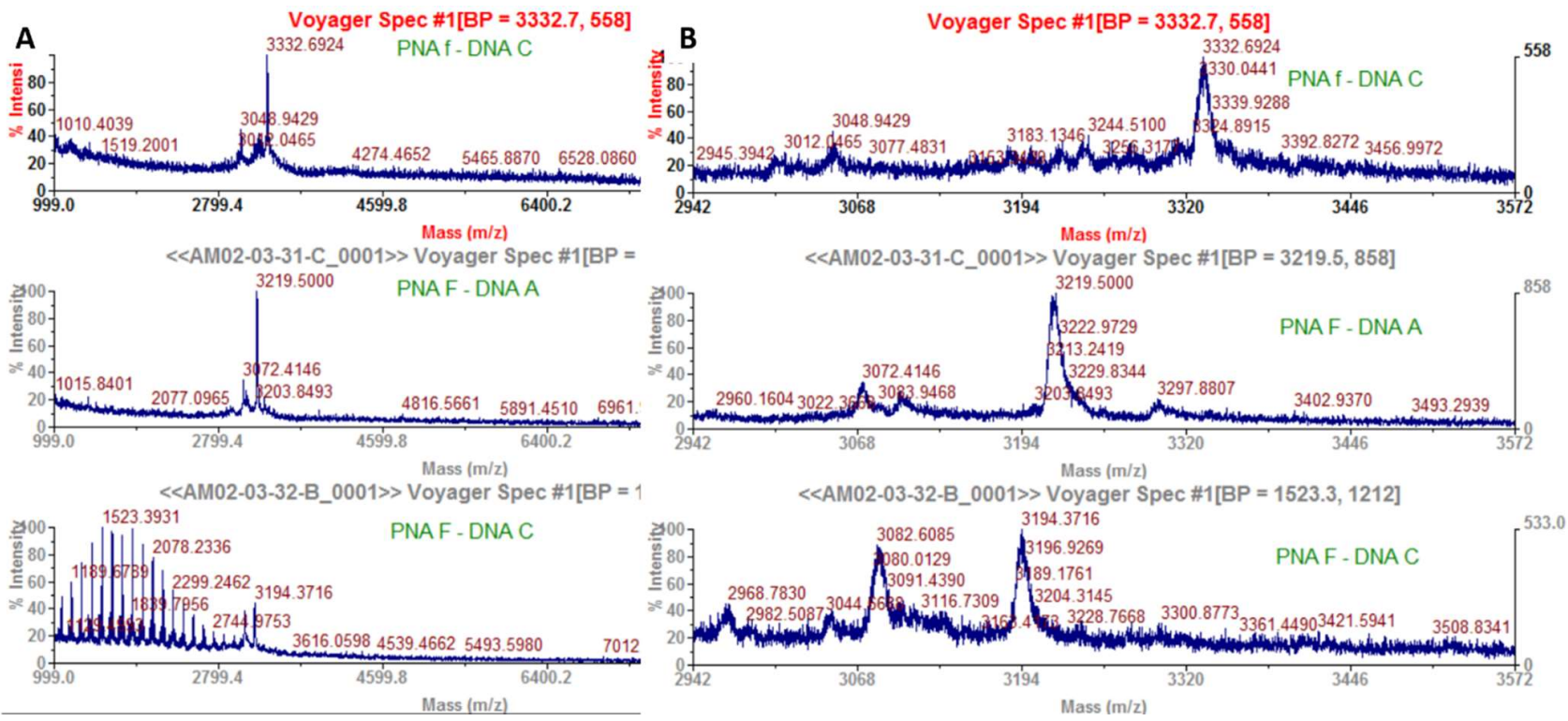

Fig. S11: MALDI spectra of the isolated peaks (A), and zoom of the region used for the peak analysis (B).

Table S4: weighted average of the ICL MALDI peaks. $\Delta$ mass calculated in respect the MW of the furan-containing PNA.

\begin{tabular}{|c|c|c|c|c|c|}
\hline \multicolumn{2}{|c|}{} & \multicolumn{2}{c|}{ DNA } & \multicolumn{2}{c|}{$\Delta$ mass } \\
\cline { 2 - 6 } \multicolumn{2}{|c|}{} & A & C & A & C \\
\hline \multirow{2}{*}{ 乙 } & f & - & 3333.4 & - & 106.3 \\
\cline { 2 - 6 } & F & 3219.1 & 3194.9 & 130.1 & 105.9 \\
\hline
\end{tabular}


Furan-PNA: a mildly inducible irreversible interstrand crosslinking system targeting single and double stranded DNA - Electronic Supporting Information

NMR spectra
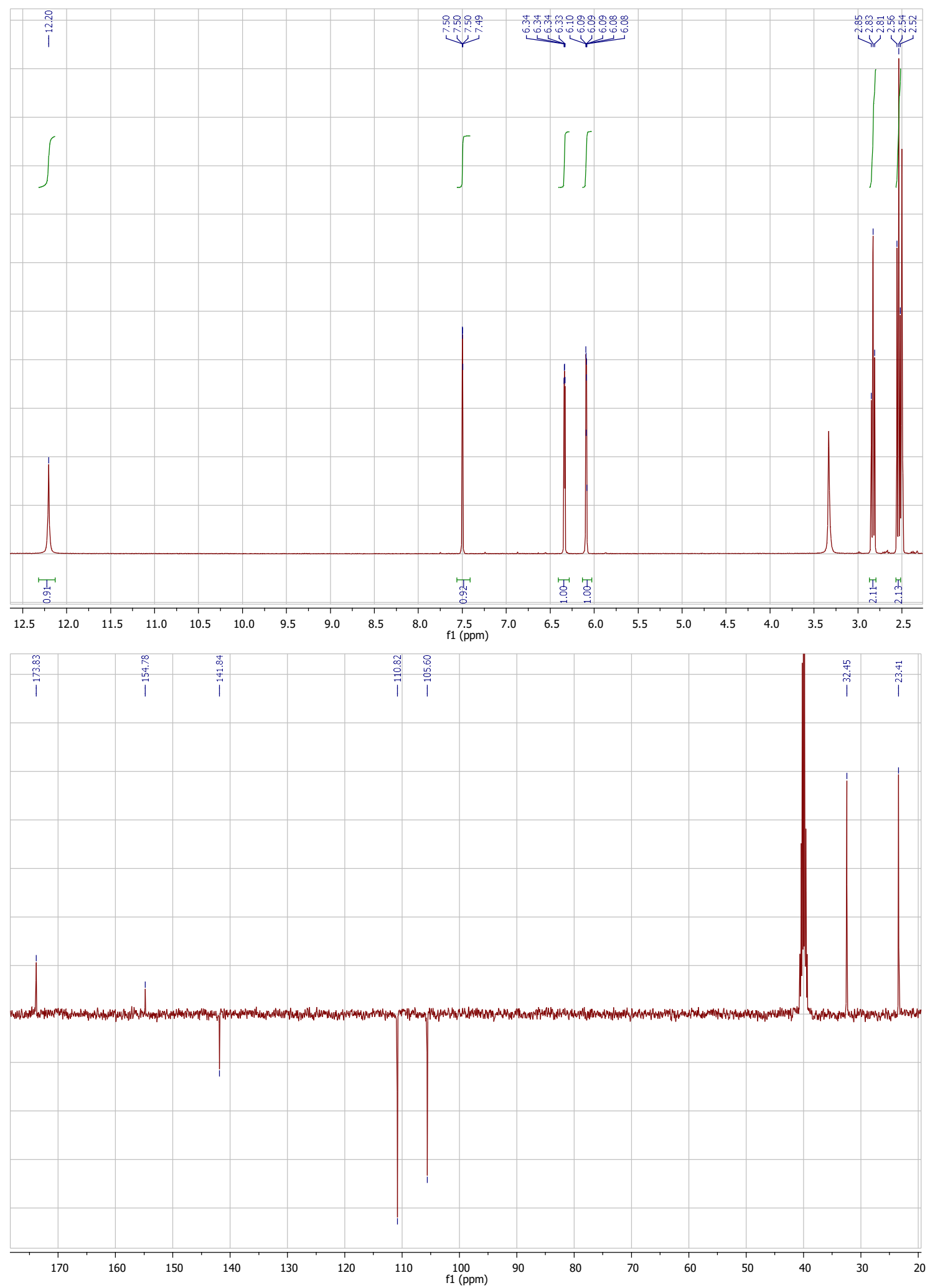

Fig. S12: ${ }^{1} \mathrm{H}-\mathrm{NMR}$ and ${ }^{13} \mathrm{C}-\mathrm{NMR}$ (APT) of compound 1 
Furan-PNA: a mildly inducible irreversible interstrand crosslinking system targeting single and double stranded DNA - Electronic Supporting Information
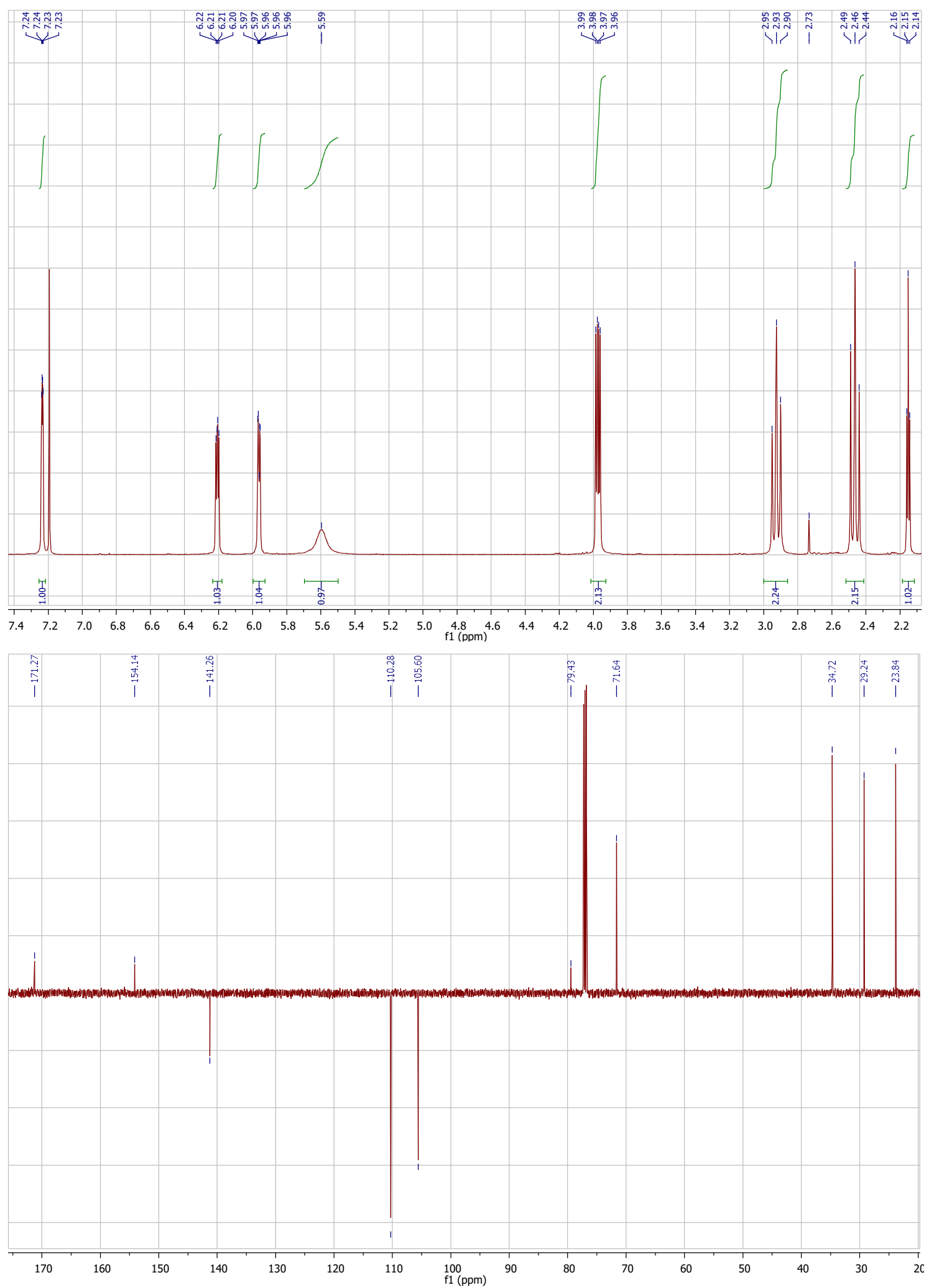

Fig. S13: ${ }^{1} \mathrm{H}-\mathrm{NMR}$ and ${ }^{13} \mathrm{C}-\mathrm{NMR}$ (APT) of compound 2 
Furan-PNA: a mildly inducible irreversible interstrand crosslinking system targeting single and double stranded DNA - Electronic Supporting Information

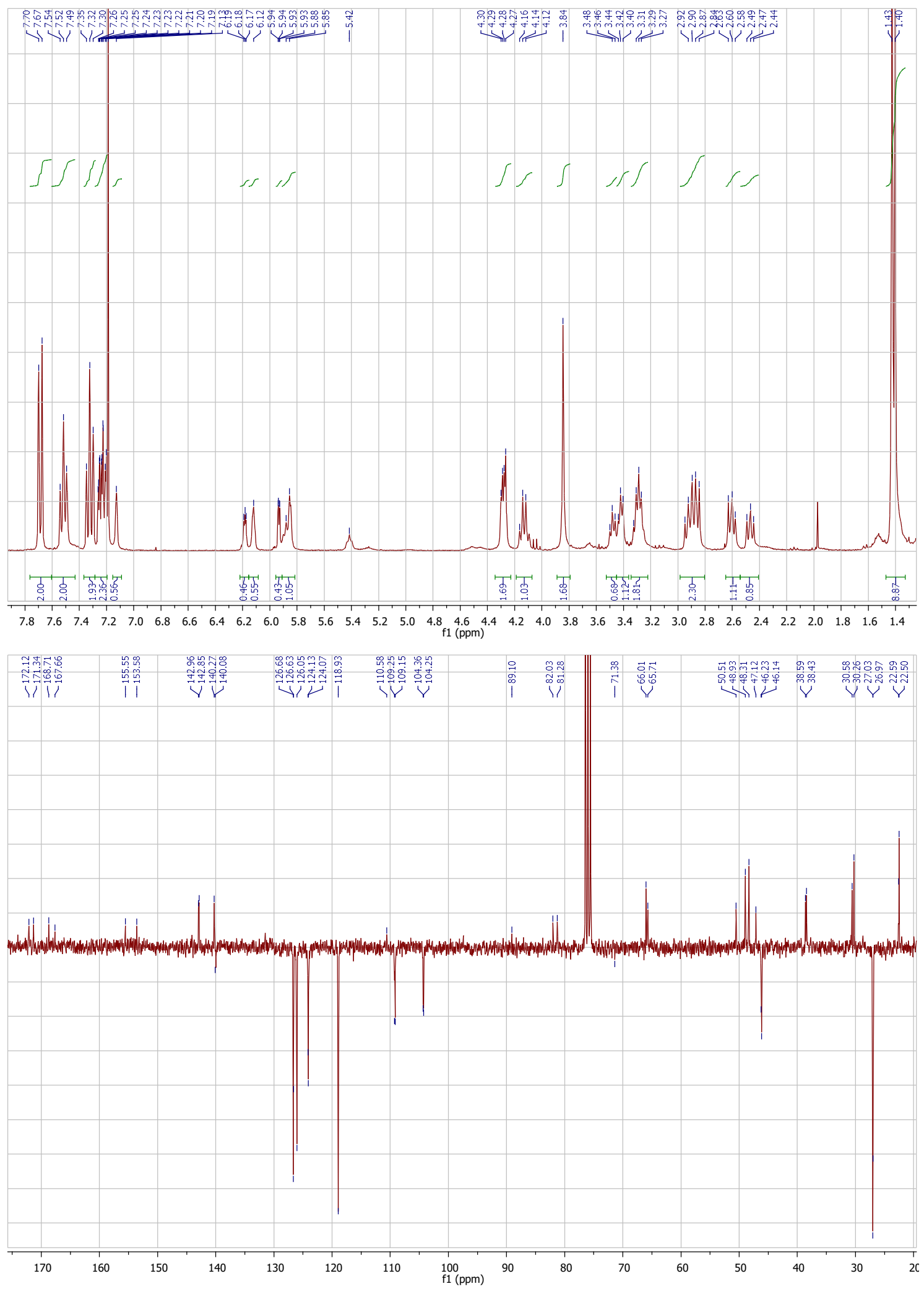

Fig. S14: ${ }^{1} \mathrm{H}-\mathrm{NMR}$ and ${ }^{13} \mathrm{C}-\mathrm{NMR}$ (APT) of compound 3 
Furan-PNA: a mildly inducible irreversible interstrand crosslinking system targeting single and double stranded DNA - Electronic Supporting Information
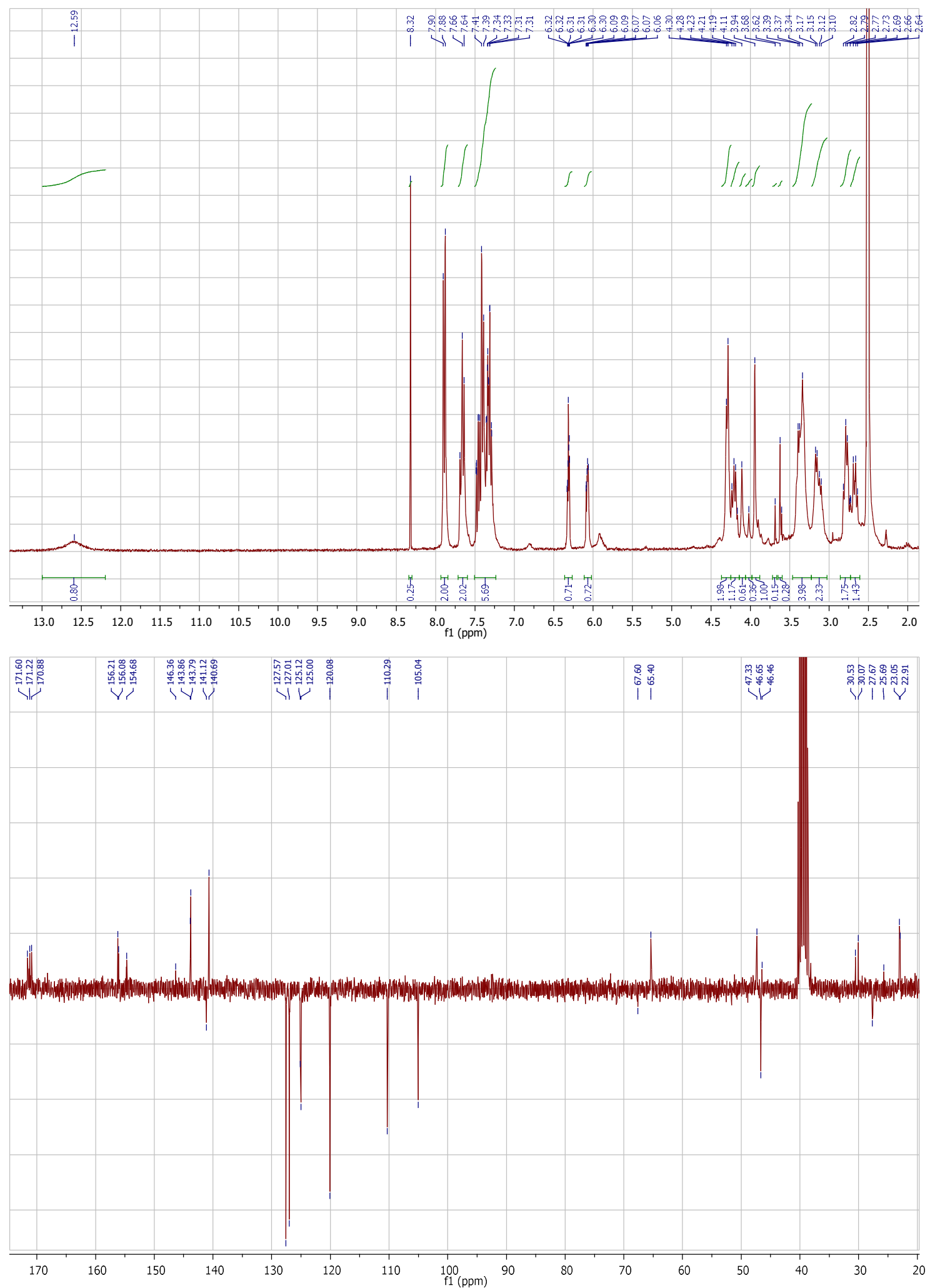

Fig. S15: ${ }^{1} \mathrm{H}-\mathrm{NMR}$ and ${ }^{13} \mathrm{C}-\mathrm{NMR}$ (APT) of compound 4 
Furan-PNA: a mildly inducible irreversible interstrand crosslinking system targeting single and double stranded DNA - Electronic Supporting Information
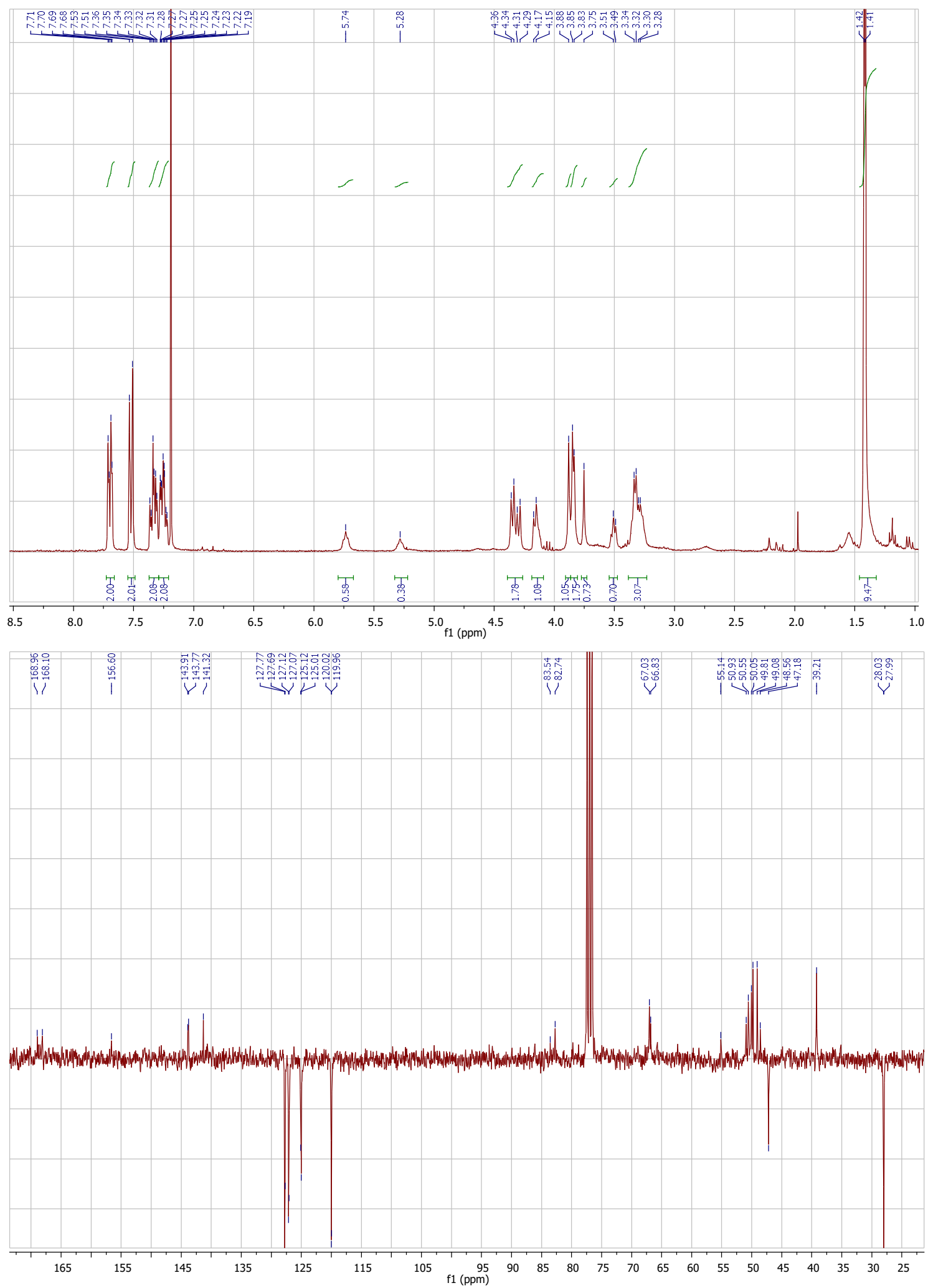

Fig. S16: ${ }^{1} \mathrm{H}-\mathrm{NMR}$ and ${ }^{13} \mathrm{C}-\mathrm{NMR}$ (APT) of compound 5 
Furan-PNA: a mildly inducible irreversible interstrand crosslinking system targeting single and double stranded DNA - Electronic Supporting Information

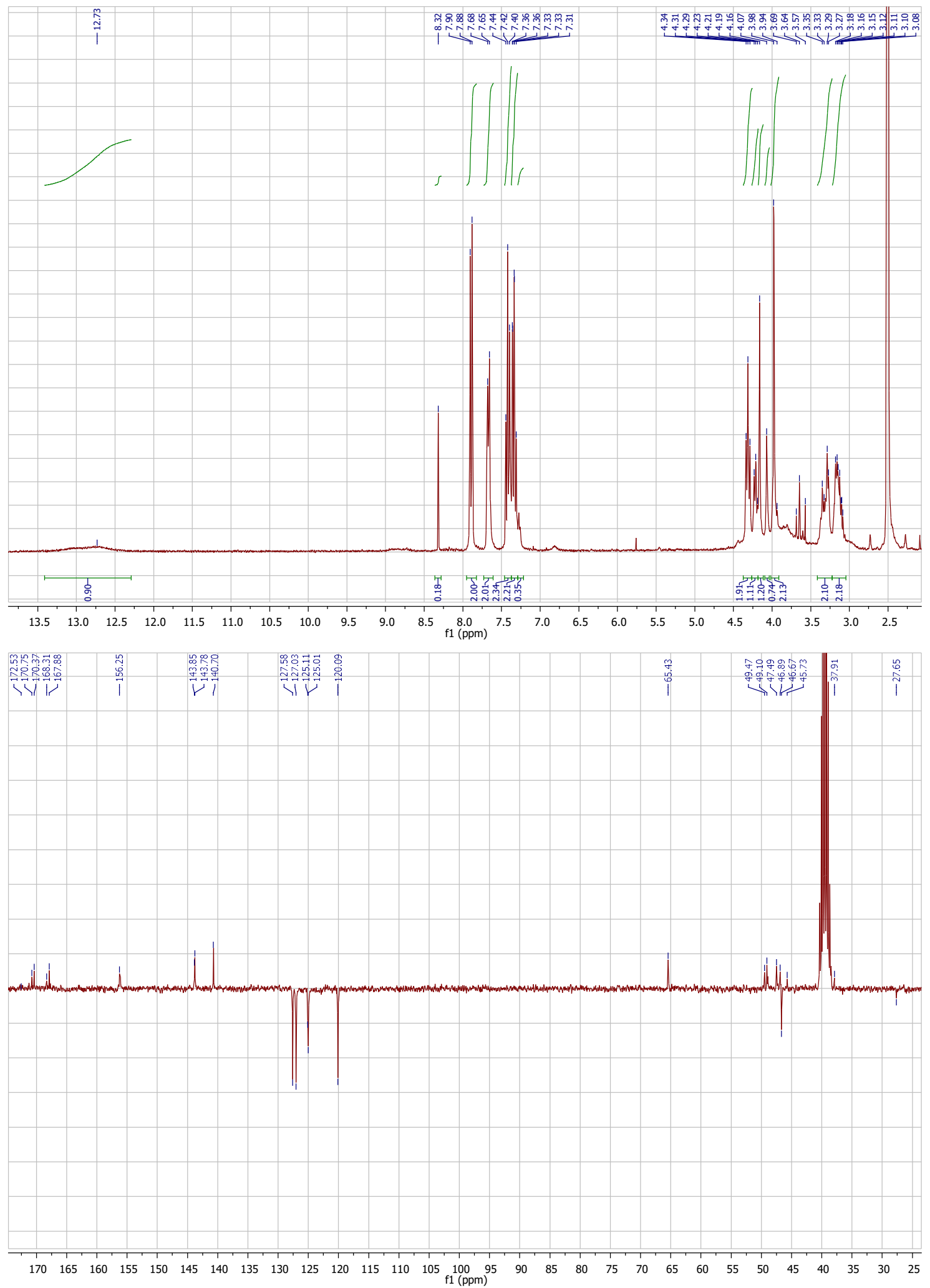

Fig. S17: ${ }^{1} \mathrm{H}-\mathrm{NMR}$ and ${ }^{13} \mathrm{C}-\mathrm{NMR}(\mathrm{APT})$ of compound 6 
Furan-PNA: a mildly inducible irreversible interstrand crosslinking system targeting single and double stranded DNA - Electronic Supporting Information

\section{UPLC-MS chromatograms}

AM5-224-A1P

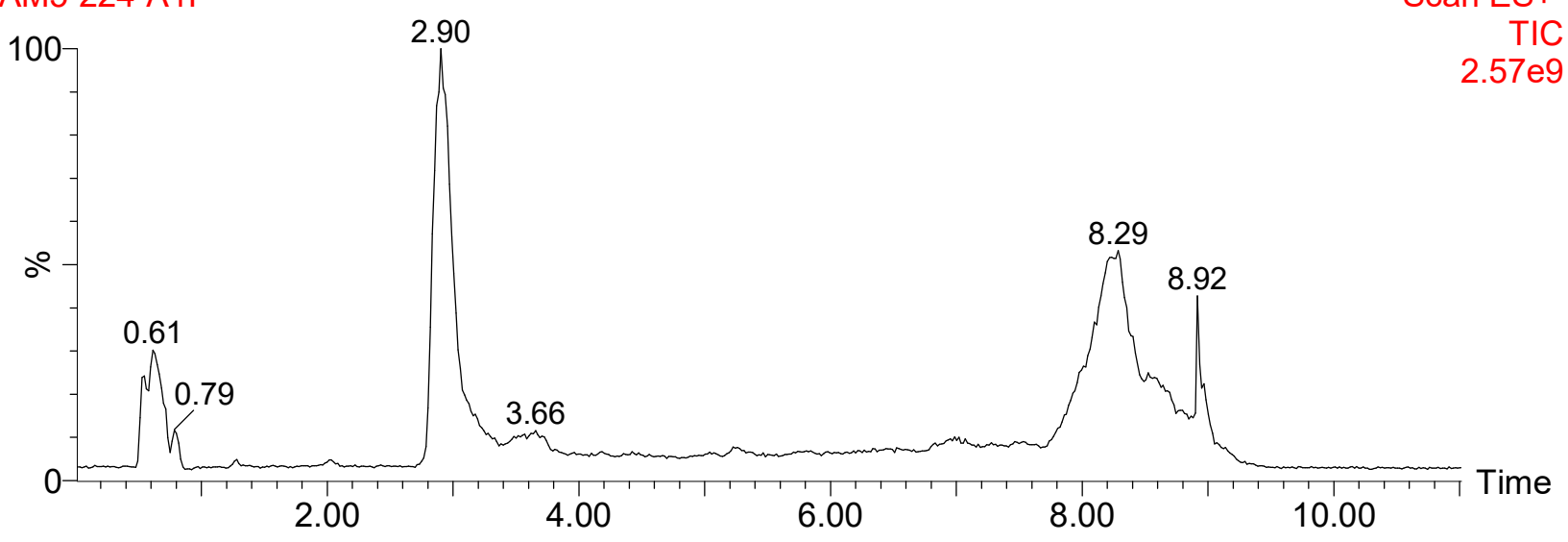

AM5-224-A1P 170 (2.904) Cm (165:180)

Scan ES+

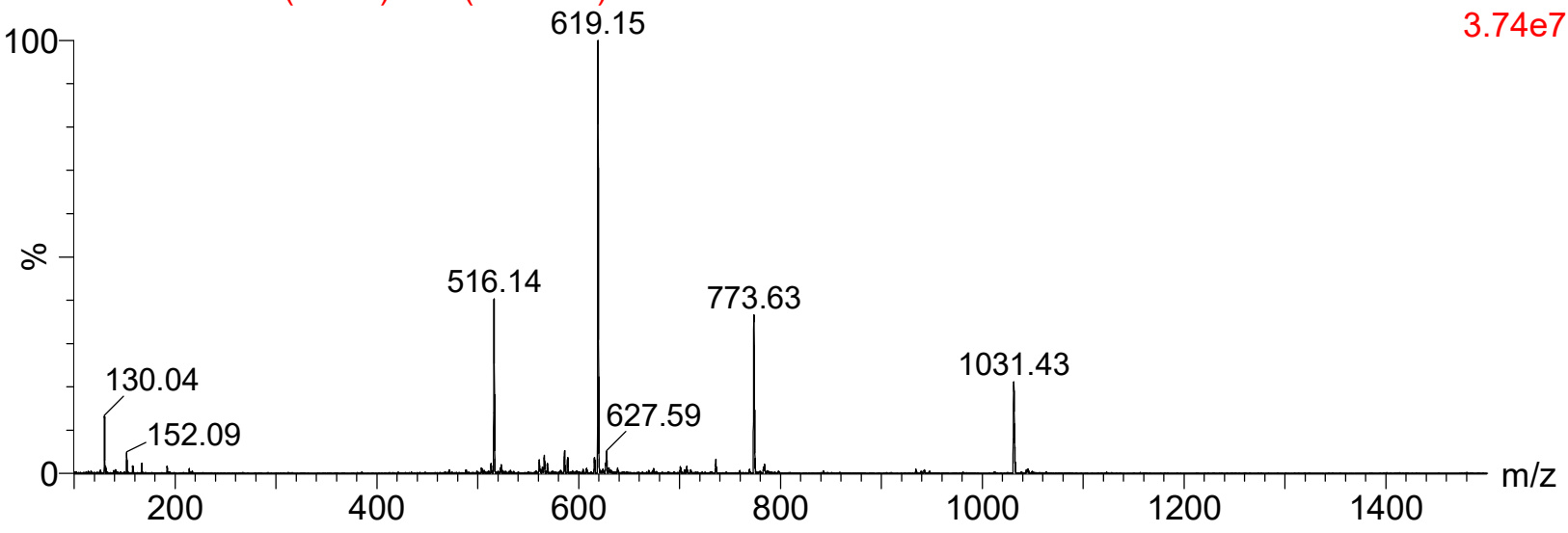

AM5-224-A1P 170 (2.904) M1 [Ev-101361,It10] (Gs,0.500,100:1500,0.10,L33,R33); Cm (155:229)

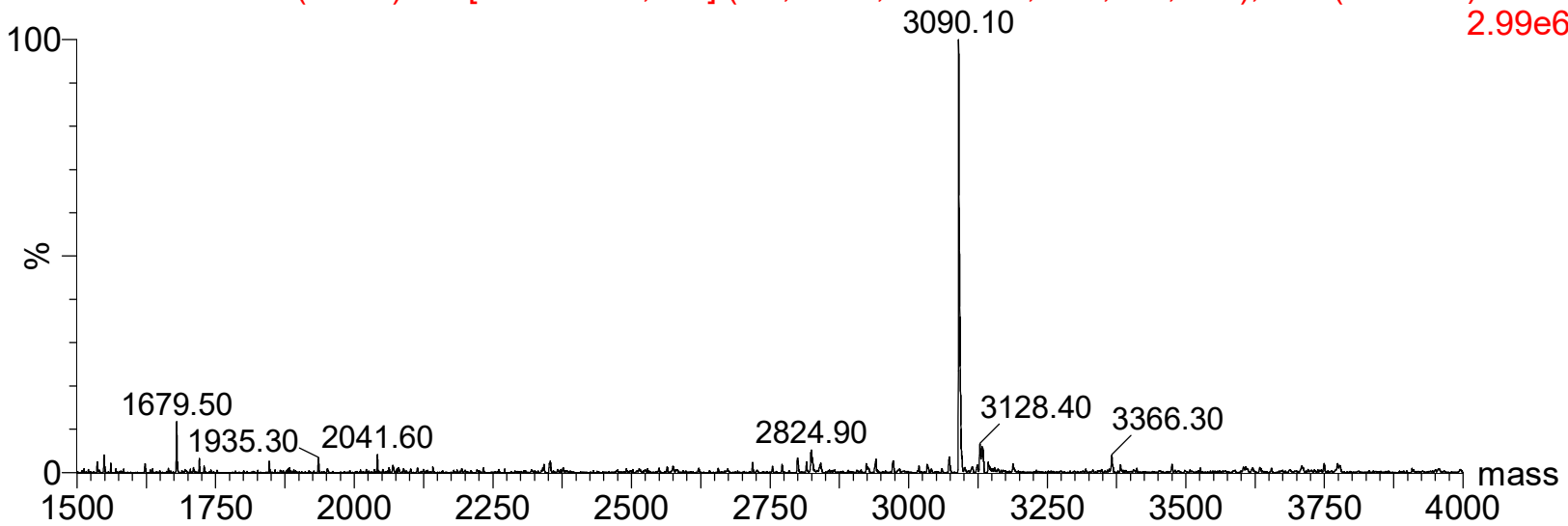

Fig. 18: UPLC-MS of PNA T: UPLC-MS trace (top), MS spectrum of the corresponding peak at 2.90 min (center) and mathematical deconvolution of the multicharged signals (bottom). 
Furan-PNA: a mildly inducible irreversible interstrand crosslinking system targeting single and double stranded DNA - Electronic Supporting Information

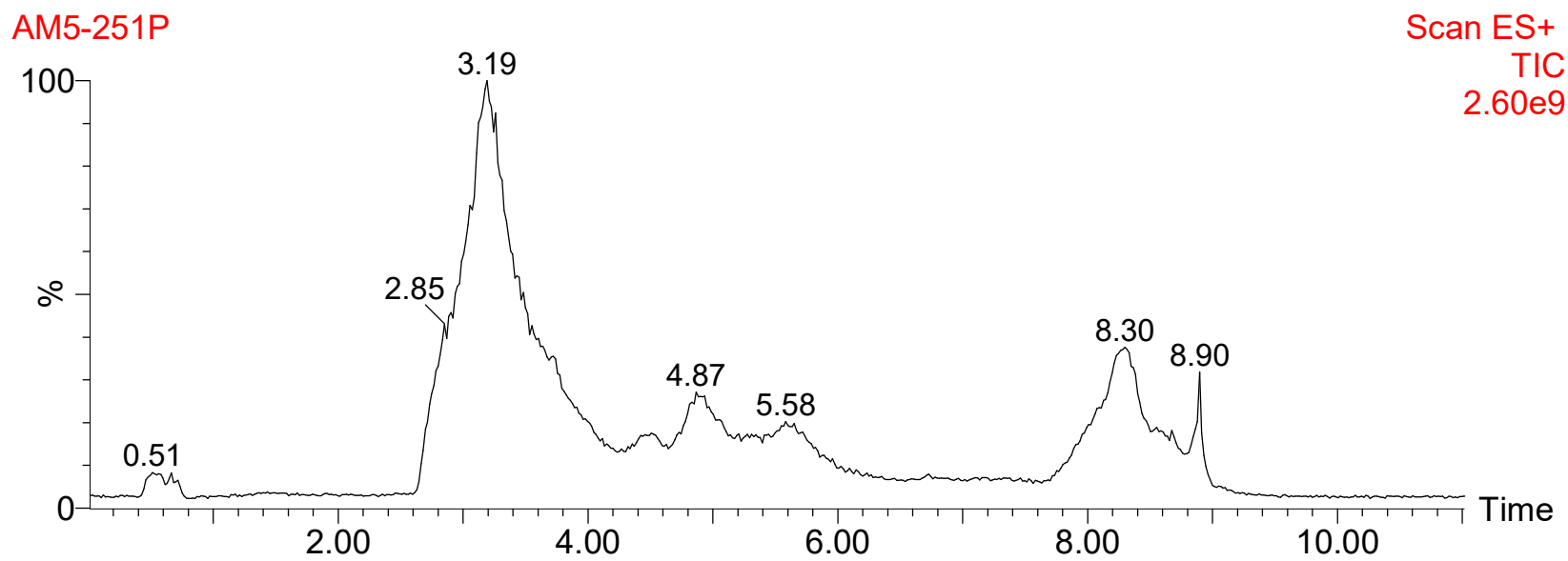

AM5-251P 187 (3.193) Cm (159:229)

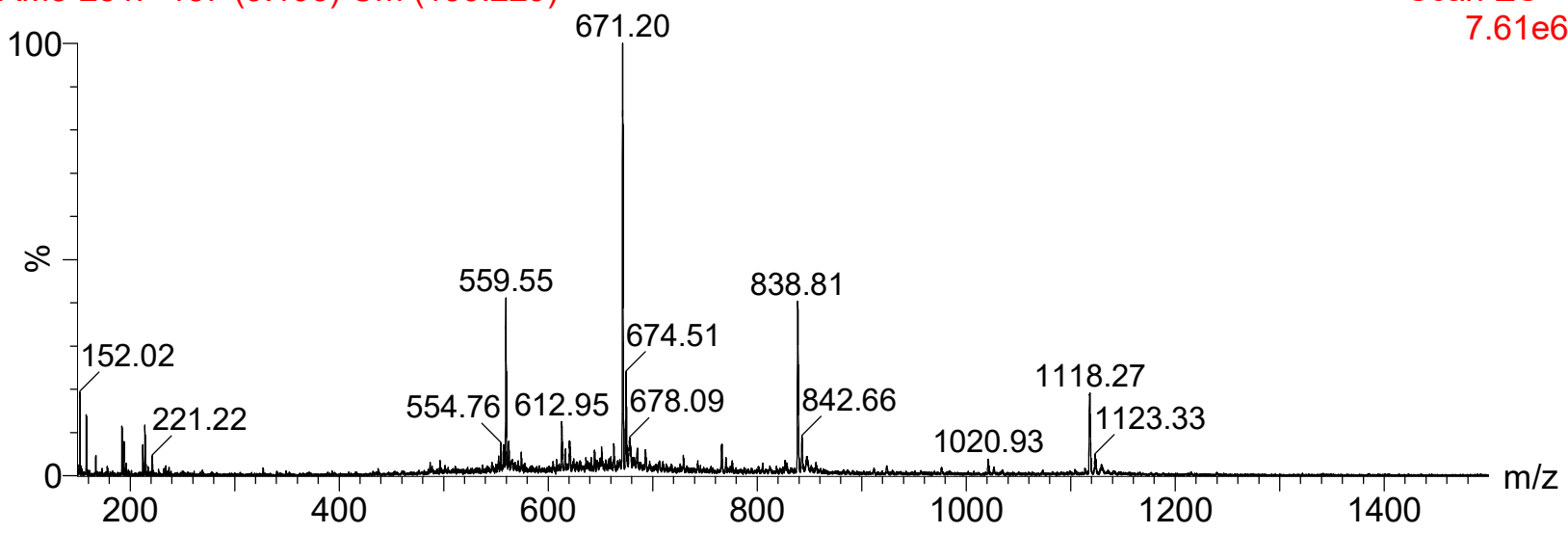

AM5-251P 187 (3.193) M1 [Ev-100027,It10] (Gs,0.500,150:1500,0.10,L33,R33); Mk [Ev-97077,It22] (Gs,

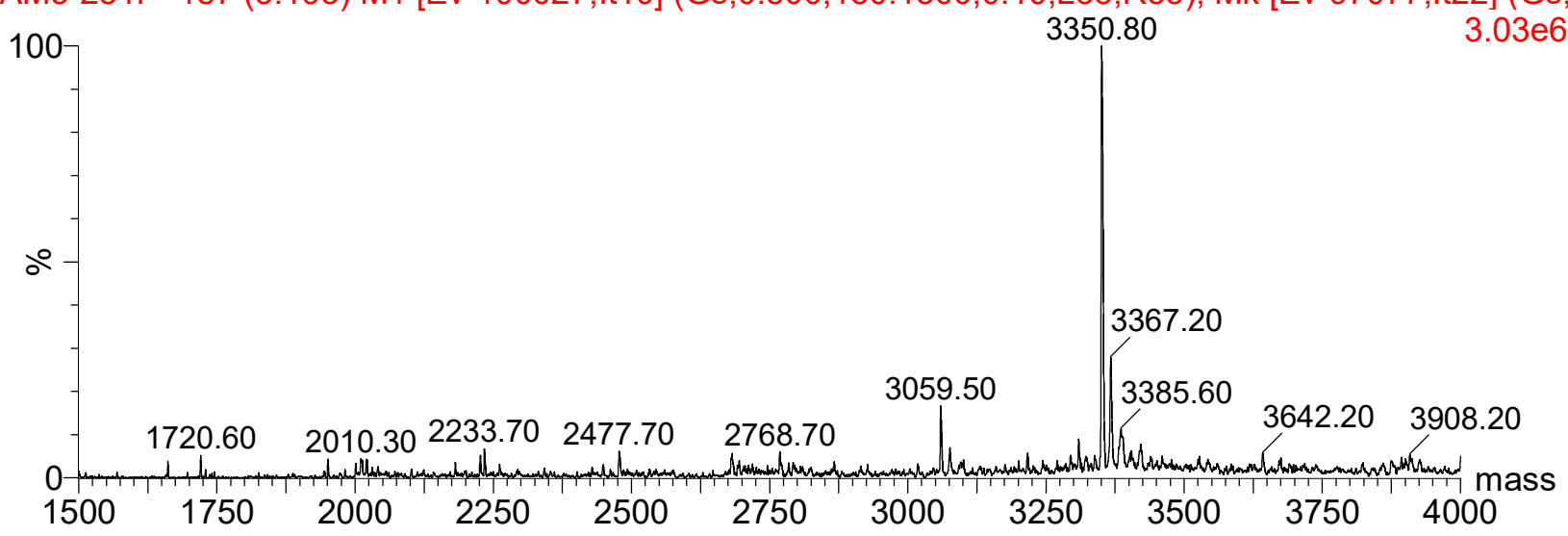

Fig. 19: UPLC-MS of PNA T(f): UPLC-MS trace (top), MS spectrum of the corresponding peak at 3.19 min (center) and mathematical deconvolution of the multicharged signals (bottom). 
Furan-PNA: a mildly inducible irreversible interstrand crosslinking system targeting single and double stranded DNA - Electronic Supporting Information

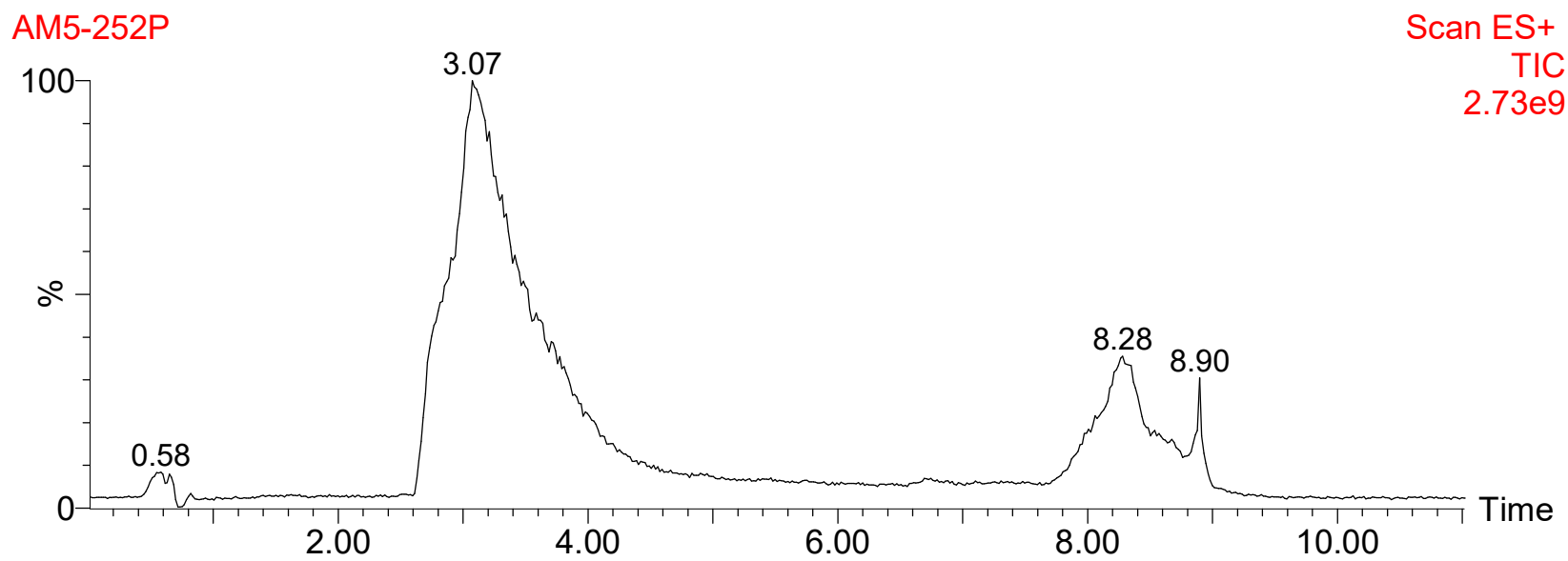

AM5-252P 180 (3.074) Cm (153:236)
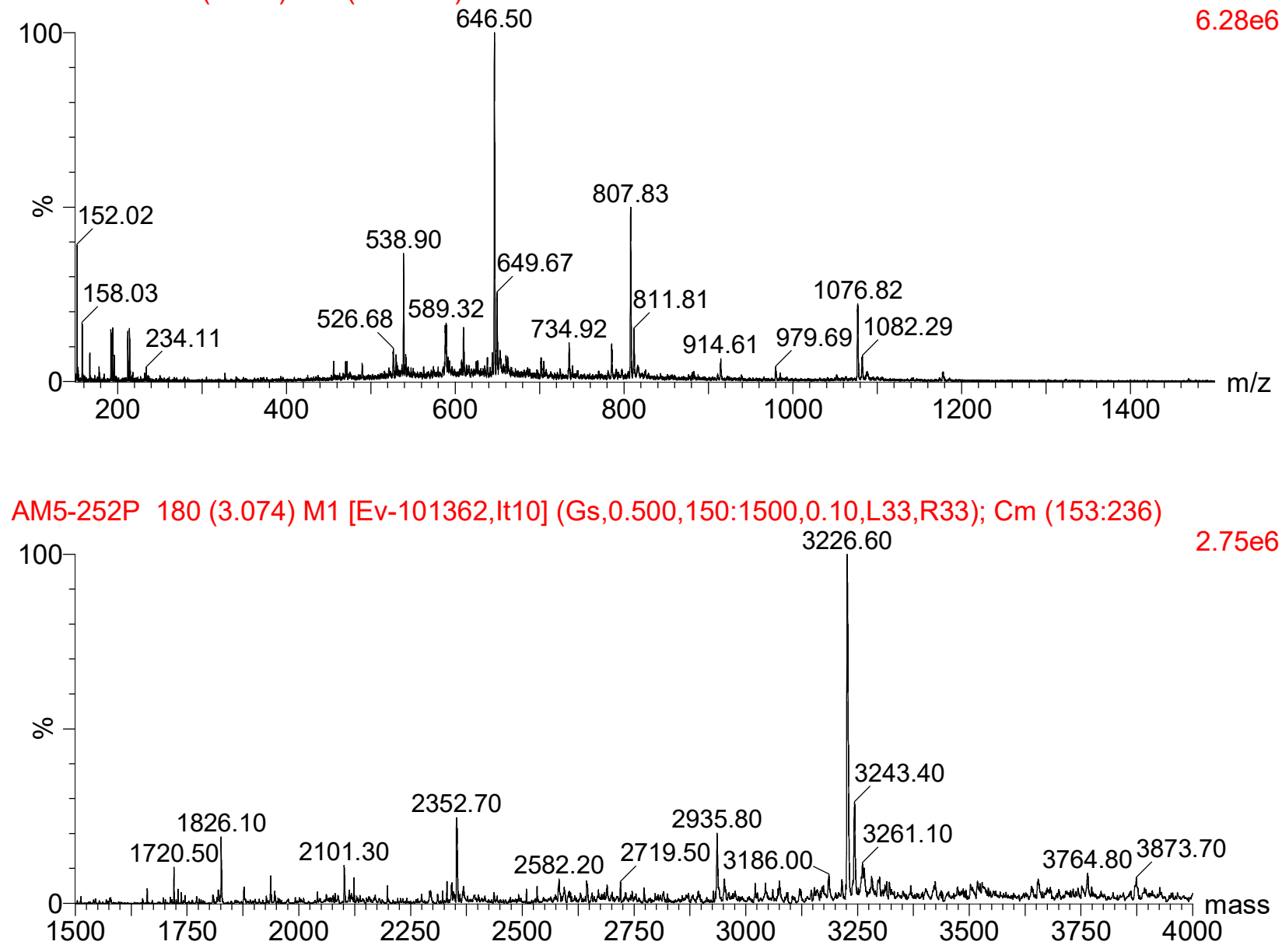

Fig. 20: UPLC-MS of PNA f: UPLC-MS trace (top), MS spectrum of the corresponding peak at 3.07 min (center) and mathematical deconvolution of the multicharged signals (bottom). 
Furan-PNA: a mildly inducible irreversible interstrand crosslinking system targeting single and double stranded DNA - Electronic Supporting Information
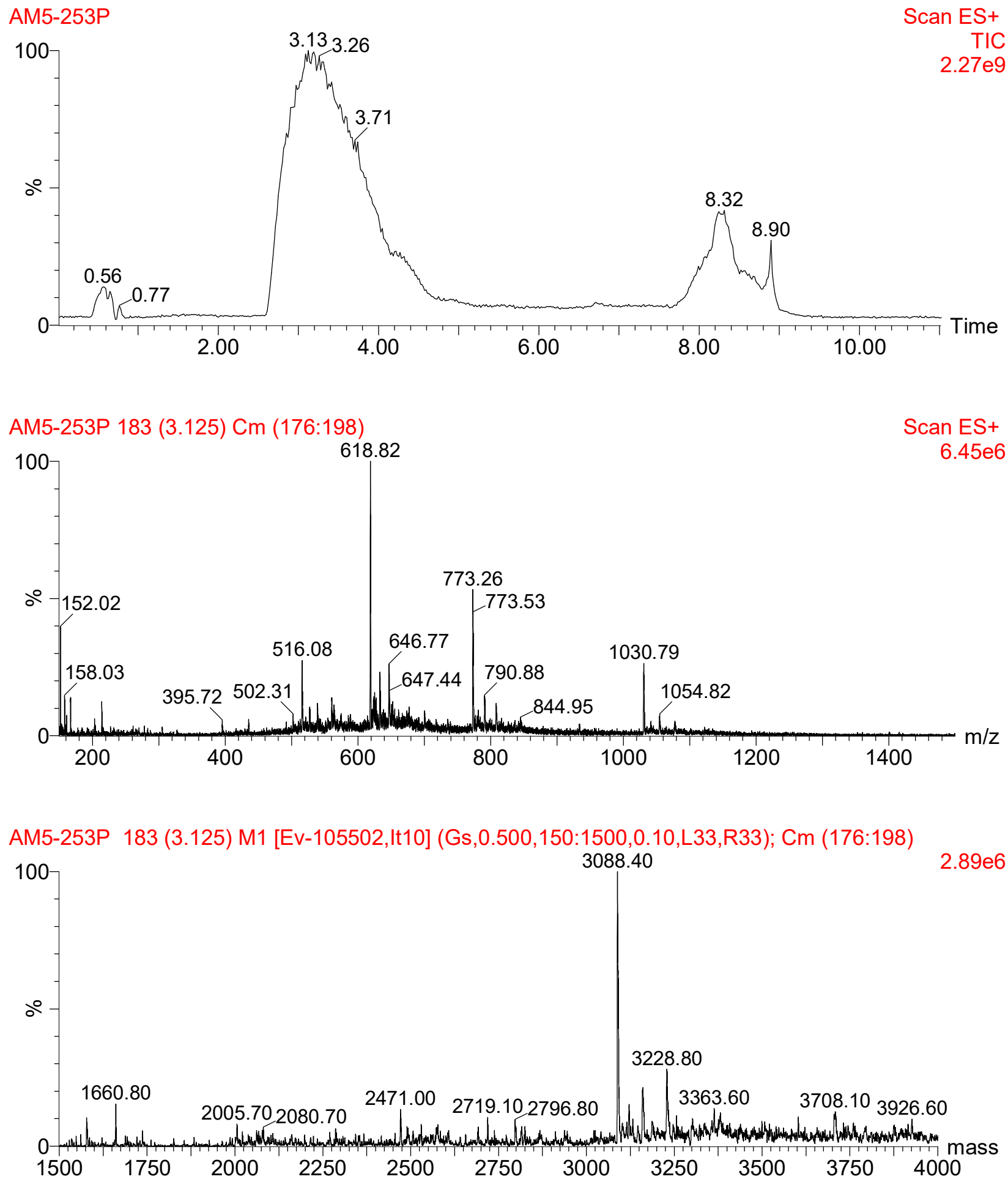

Fig. S21: UPLC-MS of PNA F: UPLC-MS trace (top), MS spectrum of the corresponding peak at $3.13 \mathrm{~min}$ (center) and mathematical deconvolution of the multicharged signals (bottom). 